\title{
Life cycle assessment of Danish pork exports using different cooling technologies and comparison of upstream supply chain efficiencies between Denmark, China and Australia
}

\author{
Bonou, Alexandra; Colley, Tracey Anne; Hauschild, Michael Zwicky; Olsen, Stig Irving; Birkved, Morten
}

Published in:

Journal of cleaner production

Link to article, DOI:

10.1016/j.jclepro.2019.118816

Publication date:

2020

Document Version

Peer reviewed version

Link back to DTU Orbit

Citation (APA):

Bonou, A., Colley, T. A., Hauschild, M. Z., Olsen, S. I., \& Birkved, M. (2020). Life cycle assessment of Danish pork exports using different cooling technologies and comparison of upstream supply chain efficiencies between Denmark, China and Australia. Journal of cleaner production, 244, [118816].

https://doi.org/10.1016/j.jclepro.2019.118816

\section{General rights}

Copyright and moral rights for the publications made accessible in the public portal are retained by the authors and/or other copyright owners and it is a condition of accessing publications that users recognise and abide by the legal requirements associated with these rights.

- Users may download and print one copy of any publication from the public portal for the purpose of private study or research.

- You may not further distribute the material or use it for any profit-making activity or commercial gain

- You may freely distribute the URL identifying the publication in the public portal 
Life cycle assessment of Danish pork exports using different cooling technologies and comparison of upstream supply chain efficiencies between Denmark, China and Australia

Please cite this article as: Alexandra Bonou, Tracey Colley, Michael Z. Hauschild, Stig Olsen, Morten Birkved (2020) Life cycle assessment of Danish pork exports using different cooling technologies and comparison of upstream supply chain efficiencies between Denmark, China and Australia. Journal of Cleaner Production 244, https://doi.org/10.1016/j.jclepro.2019.118816.

\title{
Life cycle assessment of Danish pork exports using different cooling technologies and comparison of upstream supply chain efficiencies between Denmark, China and Australia
}

\author{
Alexandra Bonou, Tracey Colley*, Michael Z. Hauschild, Stig Olsen, Morten Birkved ${ }^{1}$
}

Authors - Quantitative Sustainability Assessment Group, Sustainability Division, Department of Management Engineering, Technical University of Denmark, 2800 Kgs. Lyngby, Denmark

*Corresponding author. Email address: trco@dtu.dk/traceycolley@gmail.com,ph +454 5026 5485, fax not available

\section{Abstract:}

This study completed a cradle-to-retailer life cycle assessment of Danish export pork and provided a comparative assessment of six after cooling technologies for the supply of pork meat to three markets, Denmark, China and Australia. Nine different pork products delivered to retailers were assessed for fourteen midpoint impact categories. Given the higher efficiency of the Danish pork production system, the relatively small impact of transportation, the relatively large contribution of feed production, and the higher yield of crop production in Denmark, Danish pork production could provide a more sustainable pork supply if issues relating to consumer acceptance of superchilled products and cold chain integrity can be addressed. The human edible protein required (HEPR) in feed to produce one kilogram of human edible protein was over 4 for all supply chains, Denmark had the lowest value of 4.17, 4.27 for Australia and 4.56-5.52 for China, largely due to differences in feed conversion efficiencies. The amount of arable land required to produce one kilogram of human edible pork protein ranged from $38 \mathrm{~m}^{2}$ in Denmark, to $44-51 \mathrm{~m}^{2}$ in China and $161 \mathrm{~m}^{2}$ in Australia, due to large differences in crop yields of the feed ingredients. Pork production is therefore a net consumer of human edible protein and HEPR and arable land use are useful metrics by which to assess food supply chains. The life cycle assessment study was undertaken as part of an industry research project into new superchilling technologies, and the HEPR and arable land study was undertaken as part of a PhD on the sustainability of agribusiness value chains.

Keywords ${ }^{2}$ (6 max): pork production, supply chain, life cycle assessment, super-chilling, arable land use, human edible protein required

\section{Highlights (submit as separate document):}

\footnotetext{
${ }^{1}$ Present address - Institute of Chemical Engineering, Biotechnology and Environmental Technology (KBM), University of Southern Denmark (SDU), Campusvej 55, 5230, Odense M, Denmark, morb@kbm.sdu.dk ${ }^{2}$ Human Edible Protein Required (HEPR) is the ratio of human edible protein consumed in the feed material per kilogram of human edible protein produced.
} 
Life cycle assessment of Danish pork exports using different cooling technologies and comparison of upstream supply chain efficiencies between Denmark, China and Australia

- Superchilling extends the shelf life of "fresh" product and enables exports to distant markets

- Superchilling and transport of pork from Denmark has insignificant impacts, relative to farming

- Human Edible Protein Required (HEPR) was over four for each pork supply chain

- Arable land use ranged from 38 (Denmark) to $161 \mathrm{~m}^{2}$ (Australia) per kilogram of human edible protein

- HEPR and arable land use are useful metrics with which to assess food supply chains

\section{Introduction}

Global demand for meat has been increasing steadily, in line with increases in both the world population and the average standard of living (Dalgaard, 2007; Reckmann et al., 2013; Verge et al., 2012). Denmark has a population of 5.7 million people (Statistics Denmark, 2016) and processes 28 million pigs annually. Pork production in Denmark contributed approximately $1 \%$ of the 2017 world production of $82,482 \mathrm{M}$ tonnes, which equated to $6 \%$ of EU-28 production (Danish Agriculture \& Food Council, 2018). Nearly $90 \%$ of Danish pork production is exported, with approximately $70 \%$ of the exported meat to countries within the European Union (EU). The remaining percentage is exported to non-EU destinations, with an increasing market share to countries such as Japan, China and other South East Asia nations (Danish Agriculture \& Food Council, 2017; Hamann, 2006). The growing export trend raises sustainability related questions such as: when it comes to arable land use and the efficiency of protein production, how does meat produced in Denmark and exported overseas compare to local production in the final markets? Danish Crown (DC) is a farmer-owned co-operative in Denmark which processed 81\% of the total number of pigs in Denmark in 2017 (Danish Agriculture \& Food Council, 2018), so given the company's market share, production-related technology choices call for an in-depth environmental investigation using a comprehensive methodology such as a life cycle assessment (LCA). There have been a number of LCAs on European pork production (Basset-Mens and van der Werf, 2005; Cederberg et al., 2005; Dalgaard et al., 2007; Nguyen et al., 2011; Noya et al., 2017; Reckmann et al., 2013). These previous LCAs have consistently identified the on-farm (upstream) pig production, particularly the production of pig feed $(60 \%$ of total climate impact in Nguyen et al. 2011), as the life cycle stage which contributes the most to the environmental impacts. According to a recent review of pork LCAs (McAuliffe et al., 2016), most existing LCA studies included a limited range of mid point impact categories (MPIC), such as climate change, eutrophication and acidification, but did not include water use, land use or a measure of supply chain efficiency, such as human edible protein required. Similarly, most earlier LCAs on pork did not assess impacts from exporting to distant markets, but instead system boundaries included farm to processor gate (Reckmann et al., 2013) or farm to local or regional markets, such as Danish pork to England (Dalgaard et al., 2007). For LCA studies that did include the core meat processing life cycle stage, all report inputs for the stage as a whole and do not provide detail on the breakdown between sub processes to enable differential allocation to different pork products, meaning that results are reported for a generic weight of meat, rather than specific pork products. Laboratory scale data was available on immersion, spiral and cryogenic super-chilling technologies as part of the GlobalMeat research project, which had not previously been scaled up to industrial use and assessed in terms of the potential for using the technologies for export to distant markets. Increasing global demand therefore requires filling in existing research gaps related to two key areas: the potential 
Life cycle assessment of Danish pork exports using different cooling technologies and comparison of upstream supply chain efficiencies between Denmark, China and Australia

for super-chilling technology to increase the export of pork to distant markets as chilled (rather than frozen) product; and pork supply chain efficiencies in different markets. Although it may be technically feasible to export pork to distant markets, it is necessary to assess whether this is environmentally preferable, based on supply chain efficiencies for the respective markets.

This study investigates the influence of core pork production system efficiencies, in particular the effect of post-processing cooling technologies up until the products reach the retail markets in adequate quality. There are three target temperature ranges used to preserve meat products for transport: fresh, frozen $\left(<-12^{\circ} \mathrm{C}\right)$ and super chilled. The latter keeps a meat product at a temperature between the initial freezing temperature $\left(-1.5^{\circ} \mathrm{C}\right.$ for fresh lean meat, down to $-6.7^{\circ} \mathrm{C}$ for meat with a higher salt content) and the fully frozen temperature $\left(-12{ }^{\circ} \mathrm{C}\right)$. The resulting product temperature is low enough to significantly retard bacterial activity, but not so low that ice crystal growth causes structural damage to all of the meat (James and James, 2011). The process involves an initial surface freezing, after which the product achieves a uniform temperature distribution that is maintained during storage, transport and distribution. This has the potential to increase the shelf life by 1.4-4 times when compared to conventional chilling methods for meat products without adversely affecting product quality (Bogh-Sorensen and Zeuthen, 1984; Duun et al., 2008; Haugland and Aune, E. J. Hemmingsen, 2005; Magnussen et al., 2008). Although the technology had already been described in 1920 and it has commonly been used in seafood (Beaufort et al., 2009; Olafsdottir et al., 2006; Zhou et al., 2010), it is only recently being used more frequently for meat products.

However super-chilling is gaining momentum as it fulfils the consumer preference for higher quality fresh products (USDA Foreign Agricultural Service, 2018a). Such improvement of cooling technologies affects the level of energy consumption; the shelf life at the market and therefore the amount of food waste (Lee et al., 2015), and it is thus relevant to investigate the associated environmental benefits. The research question for this portion of the study was: can super-chilling be used to export Danish pork products to distant markets safely from a food safety perspective; if super-chilling is technically viable, which of the available technologies are the best from an environmental perspective and how does their performance compare to freezing; and how do the extra stages of super-chilling and export contribute to the overall environmental impact of the pork products. This study was commissioned by the Danish Government.

The study focuses on Danish pork production and sale into three markets: The Danish, due to it being the location of the supply chain which provided the primary data and its share in global exports; the Chinese, due to its share in global pork production and consumption and importance as the third largest export market for Denmark; and the Australian, the seventh largest export market for Denmark, a minor competitor in Asia for Danish exports and to provide a global perspective (Danish Agriculture \& Food Council, 2016).

The study then investigated the influence of upstream pork production system efficiencies and how they vary between geographic locations and production systems. Comprehensive details on Danish pork production are published annually providing mostly "bottom up" or micro metrics that analyse farm performance (Agriculture and Horticulture Development Board, 2018; Danish Agriculture \& Food Council, 2018). Danish pork production has three categories of farms: sow herds, which produce weaned piglets (about $30 \mathrm{~kg}$ ); finisher herds, where weaned piglets are grown to the slaughter weight (100-110 kg); and integrated farms, which have sows for piglet production and grow piglets to the slaughter weight (Danish Pig Research Centre (SEGES), 2016). One of the 
Life cycle assessment of Danish pork exports using different cooling technologies and comparison of upstream supply chain efficiencies between Denmark, China and Australia

efficiency metrics used is the feed conversion ratio (FCR), which are the kilograms of feed required for each kilogram of weight gain. The 2016 feed conversion ratio of Danish production was $\mathbf{2 . 6 9}$ for finishers, compared to the European average of $\mathbf{2 . 8 4}$ for finishers and 1.8 for rearing (i.e. piglets growing from the average weaning weight of $7.2 \mathrm{~kg}$ to $29.5 \mathrm{~kg}$, the average weight for transfer from rearing to finishing) (Agriculture and Horticulture Development Board, 2018). Denmark has been regulating the emissions of nitrogen and phosphorus from agriculture, such as the application of pig waste to pastures, since 1987, when the Action Plan on the Aquatic Environment (APEA I) was adopted (Environmental Protection Agency, 2017). Farmers must submit an annual fertilization account, which includes information on the total application area, catch crops and nitrogen and phosphorus load and the net effect of the Danish laws was that upstream pork production was limited by the availability of land to recycle the pig effluent. Australian pork production systems are similar to those in Denmark, and similarly, management of manure and effluent is regulated by State-based laws aimed at protecting the surrounding environment from nutrient runoff and organic loads. China is the global leader with more than $50 \%$ of global pork production (FAO, 2017). Pork production has changed significantly in the last 50 years, from backyard ( 0 - 2 pigs per farm) and traditional ( 3 - 49 pigs per farm) systems to "landless" medium (50 - 3000 pigs per farm) and industrial (over 3000 pigs per farm) systems (Bai et al., 2014). The growth in Chinese landless pig production systems has led to reduced nutrient use efficiencies and increased environmental pollution (Bai et al., 2014). However, new regulations, including the Environmental Protection Tax program which came into effect on 1 January 2018, are designed to reduce nutrient emissions from intensive livestock farming including cattle, pig, chicken and duck operations (USDA Foreign Agricultural Service, 2018a). Less data is available on Chinese pork production efficiencies and there are some discrepancies in data available (Gale, 2017). The values for finisher FCRs in Chinese industrial systems range from $\mathbf{2 . 6 8}$ (Zhou et al., 2018) for large-scale production in northern China to 3.0-3.1 for industrial farms during the period 2006-2015 and 3.1 in 2015 for backyard farms (Gale, 2017). The latter numbers equate to $8 \%$ less efficient than the $E U$ average and $15 \%$ less efficient that the Danish average for 2015) (Agriculture and Horticulture Development Board, 2018).

However, the finisher FCR metric only looks at part of the upstream pork production system. The Danish farm inventory data used for this assessment (Nguyen et al., 2011) has a whole herd FCR of

2.805, which includes all production stages (sows and finishers herds) and measures the amount of feed required to produce 1 kilogram of live weight (LW). Australian research (Wiedemann et al., 2018) documented a whole herd FCR (kg feed/ kg LW) of 3.1 for Australia using 2010-2011 data. Whole herd FCR reported per kilograms of LW still need to be corrected for the live weight to carcass weight (CW) yield (LW: CW), as these values can vary between species and production systems. The whole herd FCR ( $\mathrm{kg}$ feed/ $\mathrm{kg} \mathrm{LW}$ or $\mathrm{kg}$ feed/ $\mathrm{kg} \mathrm{CW}$ ) is an example of a meso level metric.

"Top down" or macro level metrics could be used to compare the efficiency of supply chains in different geographic locations within the same agricultural sector, or supply chains in different sectors, such as pork and beef, and as such could potentially be of interest to external stakeholders such as consumers and policy makers. Metrics have been proposed such as the tonnes of people nourished per hectare (Cassidy et al., 2013), human digestible protein yield converted into land use ratios (Van Zanten et al., 2016) or simpler metrics such as human edible protein required (HEPR) (Wiedemann, 2018). HEPR is the mass of human edible proteins in the feed material divided by the mass of human edible protein in the final product, so a value greater than 1 indicates the product is reducing the amount of human edible protein, whereas a number below value indicates the produce 
Life cycle assessment of Danish pork exports using different cooling technologies and comparison of upstream supply chain efficiencies between Denmark, China and Australia

is increasing the amount of human edible protein. Given the limited amount of arable land available in countries like China and Australia (Cheng et al., 2011; Wiedemann et al., 2017), it is useful to investigate the amount of arable land required to produce each kilogram of human edible protein. Values for these two metrics were recently reported in (Wiedemann, 2018) for Australia, the HEPR ratio was 4.27 ( $k g$ HEPR in feed to produce $1 \mathrm{~kg} \mathrm{HEPR} \mathrm{in} \mathrm{pork} \mathrm{meat)} \mathrm{and} \mathrm{the} \mathrm{arable} \mathrm{land} \mathrm{occupation}$ for the national herd was $16.1+/-3.6 \mathrm{~m}^{2}$ per $\mathrm{kg} \mathrm{LW}$. In combination, these metrics incorporate pork production efficiency with feed production efficiency in metrics that encapsulate the whole upstream section of the pork production system. The authors are not aware of any previous studies looking at HEPR or arable land use for the Chinese or Danish pork production supply chains.

The research questions for this part of the study was: what are the upstream supply chain efficiencies of the chosen markets, as measured by the HEPR and arable land required per kilogram of human edible protein produced.

\section{Methods}

\subsection{Life Cycle Assessment of 9 pork products}

This study investigated the potential improvement to the shelf life for fresh pork meat exported to foreign markets by using different cooling technologies and the resulting potential environmental benefits. It was commissioned by the GlobalMeat project, which was funded by the Ministry of Environment and Food of Denmark and The Danish AgriFish Agency, and was not intended for comparative purposes.

\subsubsection{Technology definition}

The technologies assessed in this LCA included three that are already available on an industrial scale (spirals, chilling rooms and impingement), two that are currently under development (immersion and contact) and one (cryogenic) which is currently used in limited, special applications (GlobalMeat 2013). The technologies were compared with each other and with freezing, which is the current cooling technology used and comprehensive details on each technology are available in the GlobalMeat project report (Bonou and Birkved, 2016). Nine pork products were considered (see Table 1) and for each of them, the heat capacity above and below zero was calculated using composition data from two online databases (DTU, 2016; USDA, 2016) and commonly used methods (ASHRAE, 2006) (results are provided in Appendix A, Table A.1). For the heat capacity below zero, the sensible heat from the temperate change and the latent heat of water fusion, including the mass fraction of bound water in protein ( $40 \%$ by mass) are included (ASHRAE, 2006). The temperature range of the analysis is 5 to $-1{ }^{\circ} \mathrm{C}$ i.e. $6 \mathrm{~K}$. For freezing, the final product temperature is assumed to be $-20^{\circ} \mathrm{C}$. The amount of energy required to achieve the required temperature reduction is indicated by a coefficient of performance (COP) for each technology type, which is included in Appendix A, Table A.2. When combined with the heat capacities of the nine different pork products under assessment, the COP of each technology allows the amount of electricity required for each kilogram of product to be calculated for each technology and product type as presented in Table 1 . This indicates that freezing requires between two to three times the amount of energy compared to the super-chilling technologies under assessment.

Table 1: Electricity requirements for the technologies under assessment for nine pork products (kJ/kg) 
Life cycle assessment of Danish pork exports using different cooling technologies and comparison of upstream supply chain efficiencies between Denmark, China and Australia

\begin{tabular}{|l|c|c|c|}
\hline \multirow{2}{*}{ Pork products $^{1}$} & \multicolumn{3}{|c|}{ Cooling method } \\
\cline { 2 - 4 } & $\begin{array}{c}\text { Impingement // } \\
\text { Spiral (COP 2.6) }\end{array}$ & $\begin{array}{c}\text { Immersion // Contact // } \\
\text { Chilling room (COP 3.7) }\end{array}$ & $\begin{array}{c}\text { Freezing } \\
\text { (COP 3.7) }\end{array}$ \\
\hline Tender Loin & 8.2 & 5.8 & 20.1 \\
\hline Neck bone & 7.4 & 5.2 & 16.0 \\
\hline Rib bones & 7.4 & 5.2 & 16.0 \\
\hline Minced meat & 8.0 & 5.6 & 17.4 \\
\hline Whole ham & 6.9 & 4.8 & 16.2 \\
\hline Belly (for Bacon) & 6.4 & 4.5 & 12.8 \\
\hline Tongue & 7.9 & 5.6 & 17.3 \\
\hline Heart & 8.5 & 6.0 & 18.9 \\
\hline Front feet & 7.9 & 5.5 & 16.8 \\
\hline
\end{tabular}

Note: 1) pork products of differing composition were assessed using product weights provided by the Danish Meat Research Institute (DMRI) (Nersting, 2016; Scheller Andersen, 2016) and Danish Crown (Hededal Hofer, 2016; Thy, 2016).

A model developed by DMRI (DMRI, 2016) to predict the shelf life of fresh meat was used to check that the shelf life of the assessed products exceeded the duration of the transport to market. The model is based on storage trials performed under controlled conditions with different meat products from different plants in several European countries but does not currently include freezing.

One of the weakest links in the cold chain for pork supply is the transport between the retailer and the home of the consumer, which can vary in duration and temperature, with subsequent adverse impacts on product quality and safety. Due to the difficulties in quantifying this factor and the fact that it is a larger challenge for fresh meat than for super-chilled meat, it has not been included in the current study.

\subsubsection{Product definition}

An average slaughter weight of $104 \mathrm{~kg}$ was used, based on actual plant data provided by Danish Crown, as outlined in Table 2. Water loss can range from 5.5 - 7\% between slaughter and retail for meat (James, 2002) and drip loss of $1.6 \%$ for super-chilling is possible (Hededal Hofer, 2016), so 5.9\% of the live weight was assumed to be lost as water prior to super-chilling.

Table 2: Weight specification of Danish pork products included in study (Thy, 2016)

\begin{tabular}{|c|c|c|c|}
\hline & $\%$ of live weight & Weight (kg/pig) & Comment \\
\hline Live weight & 100 & 104 & Primary data from Danish Crown \\
\hline For human use & 84 & 87.36 & Fit for human consumption \\
\hline Water/ drip loss & $5.9 \%$ & 6.1 & $\begin{array}{l}\text { From slaughter to retail sale (James, } \\
\text { 2002) }\end{array}$ \\
\hline Assessed products & $\begin{array}{c}39 \% \text { total } \\
32.74 \% \text { excluding } \\
\text { water }\end{array}$ & 34.05 & \\
\hline Tender Loin & & 1.275 & \multirow{8}{*}{ Primary data from Danish Crown } \\
\hline Neck bone & & 1.185 & \\
\hline Rib bones & & 0.573 & \\
\hline Minced meat & & 6.000 & \\
\hline Whole ham & & 15.740 & \\
\hline Belly (for bacon) & & 7.871 & \\
\hline Tongue & & 0.243 & \\
\hline Heart & & 0.324 & \\
\hline
\end{tabular}


Life cycle assessment of Danish pork exports using different cooling technologies and comparison of upstream supply chain efficiencies between Denmark, China and Australia

\begin{tabular}{|c|c|c|l|}
\hline & \% of live weight & Weight $(\mathrm{kg} / \mathrm{pig})$ & Comment \\
\hline Front feet & & 0.842 & \\
\hline Byproducts & 16 & & Not fit for human consumption \\
\hline
\end{tabular}

Note: Green shading indicates data from literature, blue shading indicates primary data provided by industry (number of digits as in original source), yellow shading indicates calculated figures.

\subsubsection{Goal, scope and system boundaries}

The goal of the LCA was to assess the environmental impact of the use of six alternative superchilling technologies on nine different pork products and the subsequent export of pork relative to the entire pork supply chain. The LCA was conducted in accordance with the International Reference Life Cycle Data System (ILCD) Handbook for LCA (EC-JRC, 2010), using an attributional approach, which is consistent with the goal situation A "micro-level decision support". The scope is reflected in the functional unit, which was " $1 \mathrm{~kg}$ of pork product delivered to the retailer", so the system boundary extended from the farm to the retailer, as outlined in Figure 1. Potential stakeholders include pork producers, retailers, policy makers, researchers and other stakeholders wanting to understand the potential contribution of super-chilling to supply chain augmentation for exporting products.

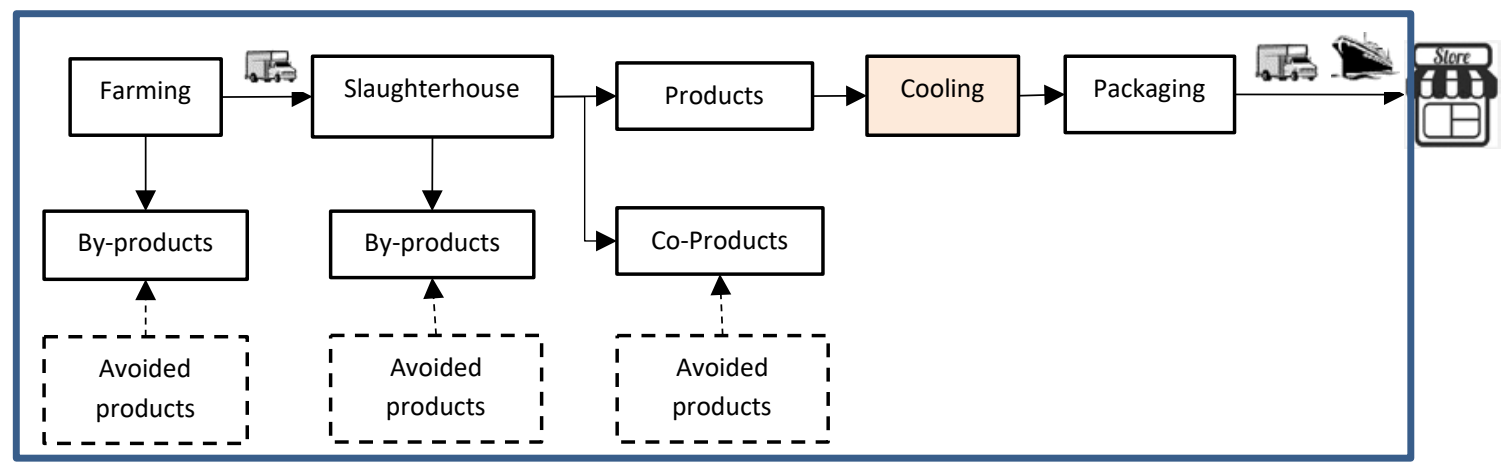

Figure 1: System boundaries for this study (indicated by the large box).

\subsubsection{Inventory and data collection}

Foreground data was used for processes relating to meat processing plants, cooling, packaging and transport, and data for the new after-cooling technologies was based on primary lab-scale data which had been scaled up to the equivalent final industrial usage using DMRI models. Background data was obtained from the Ecoinvent database v3.01 and literature. SimaPro v8.1 software was used for the modelling, the maintain consistency with the two previous LCA studies of Danish pork. The life cycle impact assessment (LCIA) methods used were ILCD 2001 midpoint, v1.07, EU27 2010, to be consistent with the Product Environmental Footprint - Product Category Rules (PEFPCR) recommendation for the assessment of meat products (TS 2016). Midpoint impact categories outlined in the PEFPCR (climate change, acidification, terrestrial eutrophication, marine eutrophication, freshwater eutrophication and land use) are reported in this paper, along with water resource depletion.

For the upstream (farm) life cycle stage, life cycle inventory data was taken from (Nguyen et al., 2011), as this is the most recent, comprehensive LCA of Danish pork production. For the meat processing life cycle stage, primary data on resource and energy consumption was provided by 
Life cycle assessment of Danish pork exports using different cooling technologies and comparison of upstream supply chain efficiencies between Denmark, China and Australia

Danish Crown (Thy 2016) and DMRI (Scheller Andersen 2016) and is summarised Table 3. Details on specific process areas are provided in Appendix A, Table A.3.

Table 3: Resource and energy consumption per live pig (104 kg live weight) allocated to specific process areas (Danish Crown and DMRI)

\begin{tabular}{|l|c|c|c|c|}
\hline & Electricity & Natural gas & Water & Liquid $^{1} \mathrm{CO}_{2}{ }^{2}$ \\
\hline Total usage/ live pig & $13.67 \mathrm{kWh}$ & $54.88 \mathrm{MJ}$ & $197 \mathrm{~L}$ & $0.56 \mathrm{~kg}$ \\
\hline Washing area & & $1 \%$ & $7.52 \%$ & \\
\hline Black slaughter line & $20 \%$ & $23 \%$ & $25.7 \%$ & $50 \%$ \\
\hline Cleaning & $14 \%$ & & $16.61 \%$ & \\
\hline Boiler (process and space heating) & & $71 \%$ & & \\
\hline Ventilation & $2 \%$ & & & \\
\hline Evaporative cooling & & & $3.5 \%$ & \\
\hline Others & $3 \%$ & & $8.04 \%$ & \\
\hline Smoking oven & & $4 \%$ & & \\
\hline Energy recovery & $0.83 \mathrm{kWh}$ & $0.58 \mathrm{kWh}$ & & \\
\hline Clean slaughter line & & & $24.36 \%$ & \\
\hline Chilling & $40 \%$ & & & \\
\hline Cutting & $5 \%$ & & $4.61 \%$ & \\
\hline Deboning & $10 \%$ & & & \\
\hline Organ processing/by-product production & $6 \%$ & & $9.65 \%$ & \\
\hline
\end{tabular}

Notes: 1) based on conversion from $\mathrm{Nm}^{3}$ using natural gas density of $0.0008 \mathrm{~kg} / \mathrm{L}$ and heating value of $\left.49 \mathrm{MJ} / \mathrm{kg}, 2\right)$ the remaining $50 \%$ is used for generic cooling purposes

Primary data on packaging was provided by Danish Crown, who indicated that $20 \mathrm{~g}$ of plastic materials were used per kilogram of meat product. It was assumed that this mass was comprised of an equal proportion of high and low density polyethylene (HDPE and LDPE), polyamide (PA), ethylene vinyl acetate, polyethylene terephthalate (PET), polystyrene (PS) and polyvinylchloride (PVC) (McMillin and Belcher, 2012). Packaged products are then put into cardboard boxes for transport and $0.055 \mathrm{~kg}$ of cardboard per kilogram of meat is used (Hededal Hofer, 2016).

For modelling product transportation to markets, a distance of $52 \mathrm{~km}$ from the Danish Crown Horsens plant to the export port of Aarhus was used and the distance by road in each country from the port to the retailer was assumed to be the same as the distance from the Horsens plant to Copenhagen $(267 \mathrm{~km})$. The distance by ship to China was representative of the distance to Australia, and assuming an average boat speed of 23 knots (Notteboom and Cariou, 2009; Sea-distances.org, 2016; Worldshipping.org, 2016), the duration of the sea voyage was calculated (Table 4).

Table 4: Distances and travel times to different markets

\begin{tabular}{|l|c|c|c|}
\hline Country & Distance by truck (km) & Distance by ship $(\mathrm{km})$ & $\begin{array}{c}\text { Time by ship } \\
\text { (days) }\end{array}$ \\
\hline Denmark & 267 & - & - \\
\hline China/ Japan/ Australia & $267+52$ & 14,413 (average) & $20-32$ \\
\hline
\end{tabular}

Regarding energy use during container transport by sea, primary data was provided by DMRI (Scheller Andersen, 2016) and is outlined in Table 5. It was assumed that the cooling was provided by liquid carbon dioxide ( $573 \mathrm{~kJ} / \mathrm{kg}$ ) for transport to Japan. Given the similarly in distance, this data was used for the China and Australia modelling. 
Life cycle assessment of Danish pork exports using different cooling technologies and comparison of upstream supply chain efficiencies between Denmark, China and Australia

Table 5: Energy consumption during transport to Japan (Scheller Andersen, 2016)

\begin{tabular}{|c|c|c|c|}
\hline Sea voyage time & \multicolumn{3}{|c|}{24.5 days } \\
\hline Container load & \multicolumn{3}{|c|}{22,000 kilograms } \\
\hline \multicolumn{4}{|c|}{ Energy consumption per container } \\
\hline & kWh container/day & $\mathrm{kg} \mathrm{C}$ & $\mathrm{O}_{2}$ used/kg product for sea voyage \\
\hline Fresh product & 22.6 & & 0.16 \\
\hline Frozen product & 34.2 & & 0.23 \\
\hline
\end{tabular}

\subsubsection{Impact allocation and handling Multifunctionality (coproducts and byproducts)}

The mass based allocation factors and comprehensive details for different production stages within the meat processing life cycle stage are outlined in Appendix A, Table A.4.

"Other inedible" byproducts (European Commission, 2005) can be further categorised using the details provided in Table 6:. Byproducts can be sent to rendering, where they are converted into meal and tallow. Some of the byproducts are suitable for producing pet food or food for animals in the fur industry, while other byproducts can be used to produce pharmaceutical products such as collagen, gelatine, peptides and proteins. Wastes with an organic content (such as the contents of the pig's digestive system, sawdust from road transport, slurry from holding pens and wastewater) can be used to produce biogas via anaerobic digestion. The biogas can then be used in a cogeneration plant to produce electricity and thermal energy, while the digestate from the anaerobic digestion can be returned to farms, offsetting the use of industrial fertilisers.

System expansion and mass allocation were used to address the multifunctionality of coproducts for human consumption and byproducts for animal feed and industrial applications, which is consistent with both the ILCD Handbook and previous studies (Dalgaard et al., 2007, 2006; Dalgaard, 2007; Nguyen et al., 2011). Primary data relating to mass yields of byproducts relative to live pig weights was provided by Danish Crown, is provided in Table 6 and comprehensive details of the allocation are provided in Appendix A, Table A.4.

Table 6: Average Danish pork products and byproducts by weight (primary data from Danish Crown, kg product/ tonne live pig) (Thy, 2016)

\begin{tabular}{|l|c|c|c|c|c|c|c|c|}
\hline & & & Product & Byproduct & Byproduct & Byproduct & Byproduct & Byproduct \\
\hline Product & Total & $\%$ & Human food & Pet food & Fur $^{1}$ & Rendering & Pharma & Biogas \\
\hline Muscle & 640 & 63 & 640 & 0 & 0 & 0 & 0 & 0 \\
\hline Bone & 132 & 13 & 114 & 0 & 2 & 16 & 0 & 0 \\
\hline Fat & 75 & 7 & 52 & 6 & 1 & 0 & 0 & 16 \\
\hline Blood & 33 & 3 & 12 & 10 & 11 & 0 & 0 & 0 \\
\hline Liver, heart & 26 & 3 & 11 & 11 & 4 & 0 & 0 & 0 \\
\hline Other byproducts & 31 & 3 & 11 & 10 & 6 & 4 & 0 & 0 \\
\hline Intestines & 19 & 2 & 1 & 6 & 5 & 1 & 2 & 4 \\
\hline Destruction & 54 & 5 & 0 & 0 & 3 & 51 & 0 & 0 \\
\hline & & & $\mathbf{8 4 0}$ & $\mathbf{4 3}$ & $\mathbf{3 2}$ & $\mathbf{7 2}$ & $\mathbf{2}$ & $\mathbf{2 0}$ \\
\hline
\end{tabular}

Note: 1 ) included in food for animals in the fur trade

Rather than modelling substitutes for final byproducts (downstream substitution) as part of the system expansion, such as the district heating and barley used in the most recent Danish LCA (Nguyen et al., 2011), the modelling replaced pork with a suitable upstream meat input based on the 
Life cycle assessment of Danish pork exports using different cooling technologies and comparison of upstream supply chain efficiencies between Denmark, China and Australia

current market share of meat consumption. The meat products to provide the upstream replacement for pork were estimated using 2014 data for slaughtered livestock weights in Denmark (EUROSTAT, 2014), which indicated that $46 \%$ was beef, $53 \%$ chicken and $1 \%$ sheep, as outlined in Appendix A, Table A.5.

The credits from pet food, fur, rendering and pharma byproducts were calculated by multiplying the mass fraction of the byproduct by the market contribution of a substitute meat product, as indicated in Appendix A, Table A.6. For biogas, it was assumed that an equivalent of $2 \%$ of the live weight as fat $(38 \mathrm{MJ} / \mathrm{kg}$ ) was converted to biogas and then used to substitute natural gas (49 MJ/kg).

\subsection{Upstream (feed and pork) production system efficiencies}

\subsubsection{Data collection for both mid point impact categories}

Whole herd FCR for Denmark and Australia were taken from literature ((Nguyen et al., 2011; Wiedemann et al., 2017). Two values were calculated for Chinese whole herd FCR based on the ratio of two reported finisher FCRs (3.1 in Gale, 2017; 2.68 in Zhou et al., 2018) to Danish finisher FCR (2.69 in AHDB Market Intelligence, 2018) for 2015, representing the best and worst cases. Australian values for HEPR and arable land use have recently been reported (Wiedemann, 2018). The quantities of different feed ingredients used in Denmark were taken from the most recent Life Cycle Assessment of Danish pork (Nguyen et al 2011) and in China from (Zhou et al., 2018) for the lower finisher FCR, and (USDA Foreign Agricultural Service, 2018b) for the higher finisher FCR. The mass of "other" in the Chinese feed ingredients was calculated using two cases, one as sprouted wheat (100\% allocation to wheat) and one as a non-grain product without land use such as fish meal.

\subsubsection{Arable land use calculation}

The origins of the feed ingredients for Denmark (Mogensen et al., 2018) and for China (USDA Foreign Agricultural Service, 2018c, 2018d) are included in Appendix B, in Table B.2 for Denmark and Tables B. 3 and B. 4 for China. Yield data for all crops was taken from the FAO online statistical database for the year 2016. To be consistent with the Australian analysis, economic allocation was used for allocating land use to coproducts, so the land area allocations were $62 \%$ to soymeal and $28 \%$ to rapeseed cake (Wiedemann, McGahan and Murphy, 2016). Recent Danish values (Mogensen et al., 2018) were used for the remaining Danish and Chinese feed components, namely $6 \%$ and $84 \%$ to wheat bran and wheat respectively, $28 \%$ to sunflower cake, $95 \%$ to palm oil and $5 \%$ to beet molasses. It was assumed that rice bran had the same economic allocation as wheat bran (6\%). This data was used to calculate the arable land required to produce one kilogram of LW and the average protein content of the feed for Denmark and China, while the Australian value was taken from literature (Wiedemann, 2018).

To provide an indication of the impact of yield on the results, the arable land area required for China and Denmark were recalculated using the worst yield within a 10 year period (2008-2017) for each feed component from all current geographic feed sources. Comprehensive details are included in Appendix B.

\subsubsection{HEPR calculation}


Life cycle assessment of Danish pork exports using different cooling technologies and comparison of upstream supply chain efficiencies between Denmark, China and Australia

The protein content of feed ingredients was taken from a variety of sources, as outlined in Appendix B, Table B.1-3. The LW:CW yield of Australia and Denmark were taken from literature $(73 \%$ and $76 \%$ respectively), the LW:CW yield for China was assumed to be the same as Australia. The CW to boneless meat yield was assumed to be $72 \%$ in all cases and the protein content of boneless pork was assumed to be $19 \%$ in all cases (Agriculture and Horticulture Development Board, 2018; Wiedemann, 2018; Wiedemann and Yan, 2014), as indicated in Table B.5 in Appendix B. The HEPRs for China and Denmark were calculated using the formula below, by dividing the total mass of edible protein in the feed ingredients per kilogram of boneless pork by the mass of edible protein per kilogram of boneless pork. The Australian value was taken from literature (Wiedemann, 2018).

$$
\text { HEPR }=\Sigma\left(P_{i} \times m_{i}\right) /\left(Y_{L W-C W} * Y_{C W-B M} * P_{B M}\right)
$$

Where $P_{\mathrm{i}}$ is the mass percent of human edible protein in each feed component $(\mathrm{kg})$

$m_{i}$ is the mass of each feed component $(\mathrm{kg})$ per kg of live weight (from whole herd FCR)

$\mathrm{Y}_{\mathrm{LW}-\mathrm{CW}}$ is the yield of cold carcase weight from live weight, assumed to be 0.73 for Australia and China, 0.76 for Denmark

$\mathrm{Y}_{\mathrm{CW}-\mathrm{BM}}$ is the yield of boneless meat from cold carcase weight, assumed to be 0.72 in all cases $\mathrm{P}_{\mathrm{BM}}$ is the human edible protein mass percentage of boneless meat, assumed to be 0.19 in all cases

3 Results \& Discussion

\subsection{LCA of 9 pork products}

\subsubsection{Product Shelf Life}

As presented in Table 7, the DMRI model indicated that super-chilling more than doubled the shelf life for pork meat when compared to current storage temperatures (row 1 compared to row 3 , and row 2 compared to row 4). It also indicated that there was sufficient shelf life available on arrival of the 9 superchilled product types (row 1 ) in the destination market after the 24.5 day sea voyage to allow for distribution and sale to consumers, ranging from 6.5 days for minced meat to 79.5 days for bacon.

Table 7: Impact of storage temperature on estimated total shelf life (days with acceptable raw meat odour) for different pork products

\begin{tabular}{|c|c|c|c|}
\hline Storage temperature & Minced Meat & Bacon $^{2}$ & Fresh cuts $^{3}$ \\
\hline$-1^{\circ} \mathrm{C}$ & 31 & 104 & 41 \\
\hline$-1^{\circ} \mathrm{C}$ then 7 days at $5^{\circ} \mathrm{C}$ & 17 & 90 & 22 \\
\hline $3.5^{\circ} \mathrm{C}^{4}$ & 13 & 38 & 17 \\
\hline $3.5^{\circ} \mathrm{C}$ then 7 days at $5{ }^{\circ} \mathrm{C}$ & 5 & 30 & 10 \\
\hline
\end{tabular}

Notes: 1) MAP-packed $\left(70 \% \mathrm{O}_{2}+30 \% \mathrm{CO}_{2}\right)$ 2) Vacuum packed, 2) $5.5 \%$ salt in aqueous (\% Sodium Chloride in the water phase, w/w), with/without Ascorbate, 60-120 ppm nitrite/nitrate added, no smoke, 3) Shelf life of fresh pork cuts - Vacuum packed and/or MAP-packed $\left(70 \% \mathrm{O}_{2}+30 \% \mathrm{CO}_{2}\right.$ ) and/or stored under aerobic conditions (on "Christmas trees" (multiple hooks), in boxes, wrapped, etc.), 4) $3.5^{\circ} \mathrm{C}$ represents conventional cooling for fresh products.

3.1.2 Assessing the whole pork supply chain 
Life cycle assessment of Danish pork exports using different cooling technologies and comparison of upstream supply chain efficiencies between Denmark, China and Australia

The analysis shows that the farming stage is the most intensive, as indicated in Figure 2. Ham exported to China or Australia that has been super-chilled using the immersion method is used, as it represents the worst case for emissions per kilogram due to the extra cooking stage required for ham during production. This is consistent with previous European LCA studies for climate change, acidification and eutrophication, and consistent with non-European LCA studies for the land use and water resource depletion impact categories.

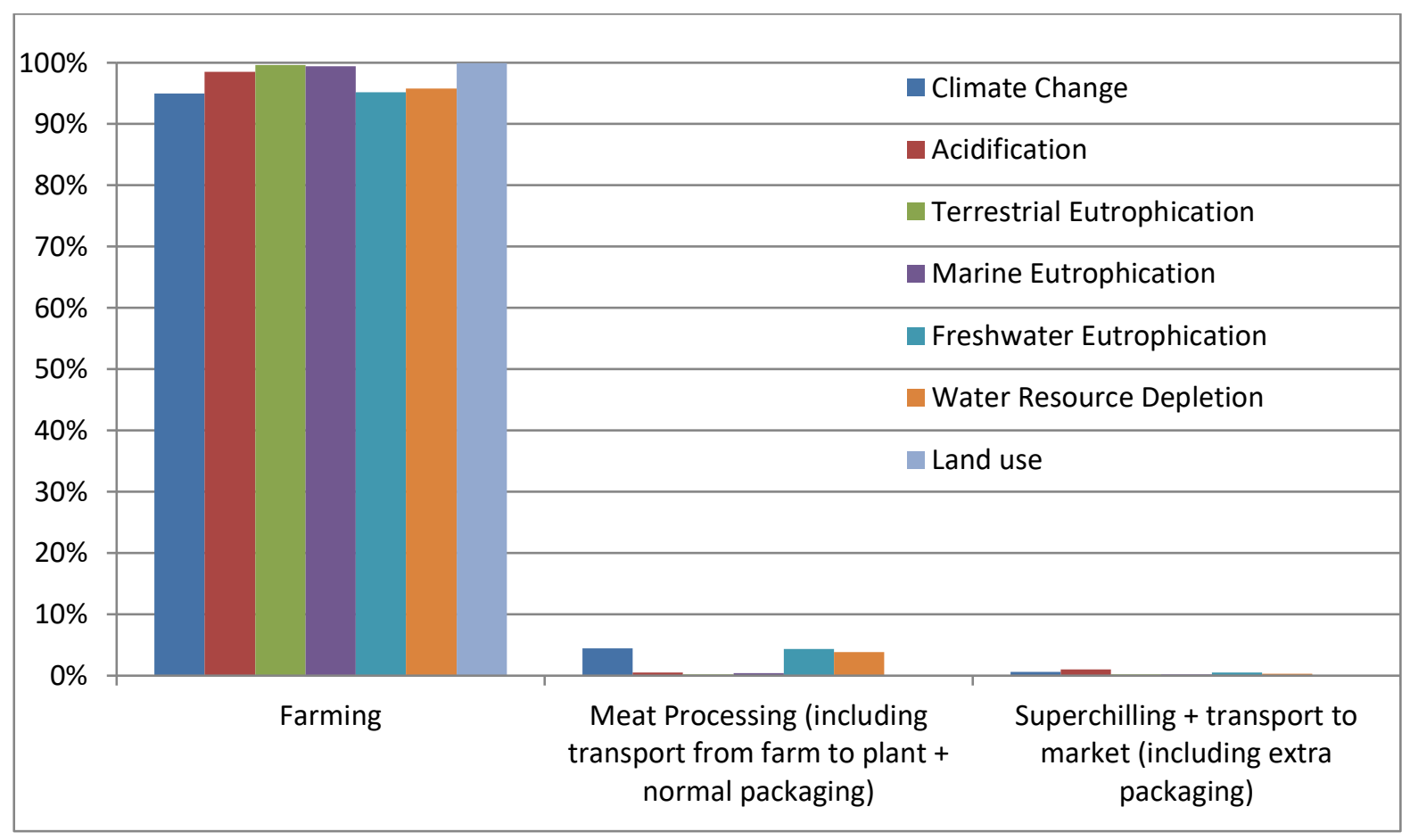

Figure 2: Relative contribution of life cycle stages of pork production for ham super-chilled using the immersion method exported to China or Australia by ship

Impacts from the farming stage ranged from $95 \%$ for climate change and freshwater eutrophication to almost $100 \%$ for terrestrial eutrophication and land use. The extra inputs that super-chilling (including extra packaging) and transport to China or Australia contributed ranged from $0 \%$ for land use to $1 \%$ for acidification, with $0.6 \%$ for climate change and $0.2 \%$ for terrestrial eutrophication respectively. A detailed breakdown is available in Appendix C, Table C.1. This is consistent with climate change impacts from other studies of meat exports over similar distances, such as a carbon footprint study of New Zealand chilled and frozen lamb export to the United Kingdom, where shipping contributed less than $5 \%$ of the climate change impacts (Ledgard et al., 2011). A similar study of chilled Australian beef and lamb exports to the USA indicated that international transport by ship contributed less than five per cent of the climate change impacts (Wiedemann et al., 2015).

The use of system expansion for the treatment of byproducts and coproducts as avoided production of meat substitutes on a mass basis results in a net credit for all categories except land use and marine eutrophication as shown in Table 8.

Table 8: System expansion for treatment of byproducts as avoided production of meat substitutes and reallocation to edible portion of pig carcass 
Life cycle assessment of Danish pork exports using different cooling technologies and comparison of upstream supply chain efficiencies between Denmark, China and Australia

\begin{tabular}{|l|c|c|c|c|}
\hline & Byproduct & $\begin{array}{c}\text { Avoided } \\
\text { production }\end{array}$ & $\begin{array}{c}\text { Net impact } \\
\text { per } \\
\text { carcase }\end{array}$ & $\begin{array}{c}\text { Net impact per } \\
\text { kg of edible } \\
\text { products }\end{array}$ \\
\hline Climate change $\left(\mathrm{kg} \mathrm{CO}_{2 \text {-eq }}\right)$ & 61.42 & -111.37 & -49.95 & -0.61 \\
\hline Acidification $\left(\right.$ molc H$_{\text {eq }}$ ) & 1.14 & -1.84 & -0.70 & -0.009 \\
\hline $\begin{array}{l}\text { Terrestrial eutrophication (molc } \\
\mathrm{N}_{\text {eq }} / \mathrm{kg} \text { ) }\end{array}$ & 5.70 & -7.49 & -1.79 & -0.022 \\
\hline Marine eutrophication $\left(\mathrm{kg} \mathrm{N}_{\text {eq }}\right)$ & 0.821 & -0.672 & 0.15 & 0.002 \\
\hline Freshwater eutrophication $\left(\mathrm{kg} \mathrm{P}_{\text {eq }}\right)$ & 0.013 & -0.141 & -0.127 & -0.002 \\
\hline Water resource depletion $\left(\mathrm{m}^{3}\right.$ water) & 0.131 & -2.206 & -2.075 & -0.025 \\
\hline Land use (kg C deficit) & $6,675.0$ & -896.3 & $5,778.7$ & 70.6 \\
\hline
\end{tabular}

\subsubsection{Assessment of super-chilling and transport options for assessed products}

Table 9 contains the climate change impact of different cuts of meat relative to different superchilling technologies and markets, after the byproducts and avoided production are credited back into the system. Products with similar results, as would be expected from the mass allocation factors and the relatively similar composition in Appendix A (Tables A.4 and A.1 respectively), are grouped together (loin/belly, neck bone/ribs, tongue/heart). This indicates that the product cut with the highest and lowest impacts are ham and feet respectively, which makes intuitive sense given that ham production involves an extra cooking stage and feet production involves the fewest stages, as they are removed early in the production process. However, uncertainty in the data used, the modelling of energy use and the mass allocation could also contribute to the differences, which highlights the need for plant studies to confirm these modelling results. Similar results were obtained for each of the impact categories and details are provided in Appendix $\mathrm{C}$ for the remaining impact categories (Tables C.2 - C.7). These climate change values are consistent with the most recent Danish study, which calculated $3.1 \mathrm{~kg}$ and $3.4 \mathrm{CO}_{2}$-e per $\mathrm{kg}$ of carcass weight using attributional (using economic allocation) and consequential (using system expansion) LCA methods respectively.

In terms of the theoretical difference between the impacts of the super-chilling technologies, immersion is the least efficient technology (due in large part to the extra packaging required to use the technology) and chilling rooms, impingement/spiral, cryogenic and contact are the most efficient super-chilling methods. The actual efficiency of chilling rooms may need to be reviewed, as there is some evidence from energy audits in similar industries in other countries that the product load can contribute as little as $20 \%$ of the total chiller load, depending on the chiller design, layout and associated usage issues such as door management (Hydro Tasmania Consulting, 2009). Additionally, contact super-chilling is not suitable for irregularly shaped cuts of pork such as ribs, neck bones and feet.

Unsurprisingly, impacts for the products transported to overseas markets were highest for China and Australia, due to the extra burden associated with transport fuel consumption and refrigeration during transport. However, the increment of impacts relating to market location was not significant.

Table 9: Cradle-to-retailer Climate change impacts ( $\mathrm{kg} \mathrm{CO}_{2-\mathrm{e}} / \mathrm{kg}$ cut) after re-allocation of byproducts and avoided production 
Life cycle assessment of Danish pork exports using different cooling technologies and comparison of upstream supply chain efficiencies between Denmark, China and Australia

\begin{tabular}{|c|c|c|c|c|c|c|c|c|}
\hline Market & Technology & 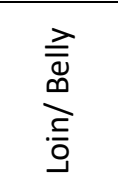 & 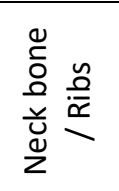 & $\begin{array}{l}\frac{\varepsilon}{\pi} \\
\frac{\pi}{1}\end{array}$ & 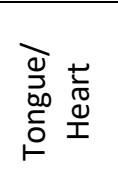 & 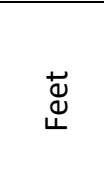 & 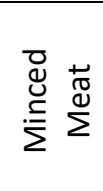 & 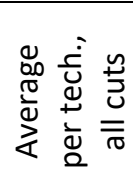 \\
\hline \multirow[t]{5}{*}{ Denmark } & $\begin{array}{l}\text { Impingement } \\
\text { \& spiral }\end{array}$ & 3.424 & 3.424 & 3.483 & 3.393 & 3.371 & 3.412 & 3.416 \\
\hline & Immersion & 3.441 & 3.441 & 3.500 & 3.410 & 3.388 & 3.428 & 3.433 \\
\hline & Chilling room & 3.424 & 3.423 & 3.483 & 3.393 & 3.371 & 3.411 & 3.416 \\
\hline & Contact & 3.424 & $x$ & 3.483 & 3.393 & $x$ & 3.411 & 3.421 \\
\hline & Cryogenic & 3.425 & 3.424 & 3.484 & 3.394 & 3.372 & 3.412 & 3.417 \\
\hline \multirow[t]{5}{*}{$\begin{array}{l}\text { China, } \\
\text { Australia }\end{array}$} & $\begin{array}{l}\text { Impingement } \\
\& \text { spiral }\end{array}$ & 3.716 & 3.716 & 3.775 & 3.685 & 3.663 & 3.704 & 3.708 \\
\hline & Immersion & 3.733 & 3.732 & 3.792 & 3.702 & 3.680 & 3.720 & 3.725 \\
\hline & Chilling room & 3.715 & 3.715 & 3.775 & 3.685 & 3.663 & 3.703 & 3.708 \\
\hline & Contact & 3.715 & $\mathrm{x}$ & 3.775 & 3.685 & $\mathrm{x}$ & 3.703 & 3.713 \\
\hline & Cryogenic & 3.716 & 3.716 & 3.776 & 3.686 & 3.664 & 3.704 & 3.709 \\
\hline
\end{tabular}

\subsection{Comparing upstream pork production efficiencies}

As presented in Table 10, HEPR values indicate that all pork production systems require over 4 kilogram of edible protein from arable sources to produce one kilogram of edible human protein in the form of pork meat. Denmark has the lowest HEPR value, 4.17 , which reflects the lower whole herd FCR. Australia was next with 4.27, in part due to the lower average protein content of the feed from arable sources in Australia (14.1\% for Australia compared to 15.3\% for Denmark and 15.9 $17.0 \%$ for China). This is a result of a higher proportion of the protein in the Australian feed mix being sourced from non-plant sources such as blood meal (85\% protein), meat and bone meal (50\% protein) and other protein meal. Chinese HEPR values range from 4.56 to 5.52 , a ratio of 1.09 to 1.32 higher than Danish values, due to the lower feed conversion efficiency and higher protein percentage from arable sources. Unsurprisingly, the two Chinese cases using sprouted wheat, where $100 \%$ of the wheat land use is allocated to the pork production, have the highest HEPR values (4.75 for the best case and 5.52 for the worst case). All pork supply chains are net consumer of human edible protein, as the HEPR values are above one.

More than four times as much arable land is required in Australia to produce an equivalent mass of edible pork protein compared to Denmark, mostly due to the lower yield per hectare of feed ingredients but also partly due to the lower feed conversion efficiency. All the Chinese cases are slightly higher than Denmark (ratios of 1.11 to 1.40), due to the lower crop yields and higher whole herd FCR. Both the non-grain China cases require smaller amounts of arable land than the sprouted wheat cases, which is as expected. As indicated in the last three rows of the table, reduced yields of livestock feed increase the area of arable land required to produce human edible protein by $26-34 \%$, with the greatest increase in Australia (34\%), followed by China (29-33\%), with Denmark having the smallest but still significant increase in land area required of $26 \%$. The lowest yields in China for corn, soy beans, wheat and sorghum were recorded in 2009, which corresponds with a period of drought from October 2008 through until February 2009 in northern China, the main grain growing area for wheat (USDA Foreign Agricultural Service, 2009). The lowest soybean yield of $0.18 \mathrm{~kg} / \mathrm{m}^{2}$ was recorded in Argentina in 2009, which coincided with a drought (NASA Earth Observatory, 2009). 
Life cycle assessment of Danish pork exports using different cooling technologies and comparison of upstream supply chain efficiencies between Denmark, China and Australia

Droughts are predicted to become more frequent, severe and longer in duration with climate change.

Table 10: Whole Herd FCR, HEPR and arable land area required to grow feed to produce $1 \mathrm{~kg}$ of human edible pork protein using 2016 FAO yield data (bold text indicates existing values from literature, ratios are in comparison to Danish values).

\begin{tabular}{|c|c|c|c|c|c|c|c|}
\hline & \multirow[t]{2}{*}{ Unit } & \multirow{2}{*}{ Australia $^{1}$} & \multirow{2}{*}{ Denmark $^{2}$} & China $^{3}$ & China $^{4}$ & China $^{3}$ & China $^{4}$ \\
\hline & & & & \multicolumn{2}{|c|}{ Sprouted wheat } & \multicolumn{2}{|c|}{ Non-grain } \\
\hline \multirow{2}{*}{$\begin{array}{l}\text { Whole Herd } \\
\text { FCR }\end{array}$} & $\mathrm{kg}$ feed/ kg LW & 3.14 & 2.81 & 2.80 & 3.24 & 2.80 & 3.20 \\
\hline & ratio & 1.1 & 1 & 1 & 1.2 & 1 & 1.2 \\
\hline $\begin{array}{l}\text { Feed Protein } \\
\text { (from arable) }\end{array}$ & $\%$ & $14.1 \%$ & $15.3 \%$ & $16.9 \%$ & $17.0 \%$ & $16.3 \%$ & $15.9 \%$ \\
\hline \multirow[t]{2}{*}{ HEPR } & $\begin{array}{l}\text { kg HEP in feed / } \\
\text { kg HEP produced }\end{array}$ & 4.27 & 4.17 & 4.75 & 5.52 & 4.56 & 5.14 \\
\hline & ratio & 1.02 & 1 & 1.14 & 1.32 & 1.09 & 1.23 \\
\hline \multirow{2}{*}{$\begin{array}{l}\text { Arable land } \\
\text { required }\end{array}$} & $\mathrm{m}^{2} / \mathrm{kg} \mathrm{HEP}$ & 161.22 & 37.99 & 44.33 & 50.99 & 40.91 & 44.21 \\
\hline & ratio & 4.24 & 1 & 1.17 & 1.34 & 1.08 & 1.16 \\
\hline \multirow{2}{*}{$\begin{array}{l}\text { Arable land } \\
\text { required } \\
\text { (low yield) }\end{array}$} & $\mathrm{m}^{2} / \mathrm{kg} \mathrm{HEP}$ & 215.47 & 47.84 & 57.39 & 67.14 & 53.24 & 58.92 \\
\hline & ratio & 4.5 & 1 & 1.20 & 1.40 & 1.11 & 1.23 \\
\hline \multicolumn{2}{|c|}{$\begin{array}{l}\text { \% difference between Arable land } \\
\text { required for } 2016 \text { vs low yield }\end{array}$} & $34 \%$ & $26 \%$ & $29 \%$ & $32 \%$ & $30 \%$ & $33 \%$ \\
\hline
\end{tabular}

Notes: 1) (Wiedemann, McGahan and Murphy, 2016), 2) (Nguyen et al., 2011), 3) (Zhou et al., 2018), 4) (Gale, 2017).

Soy production in Brazil is depleting soil nutrients (Cazemier, 2016), and it is expected that yields will decrease over time, so that soy imports from that geographic location will gradually increase the arable land required for pork production.

The combined impact of climate change and nutrient depletion means that any LCA on a livestock production system is dependant on crop yield data for the feed production system used at the time of the assessment. Crop yield data would therefore need to be revisited on a regular basis to analyse how whole herd FCR, HEPR and arable land requirements are changing with time and how this impacts the LCA results.

\subsection{Limitations and Uncertainty in the assessment}

In terms of methodological choices, the LCA results are sensitive to the way multifunctionality is handled via system expansion and substitution. Using ham as the example, the magnitude of the impacts from the system expansion and substitution ranged from relatively insignificant reductions ( $4 \%$ and $6 \%$ for marine and terrestrial eutrophication respectively) to moderate reductions ( $16 \%$ for climate change and $12 \%$ for acidification) as indicated in Figure 3. For freshwater eutrophication and water resource depletion, the net impact was very significant (over 100\%) and changed the category from being a positive emission (source) to a negative (sink). This can partly be attributed to a reduction in phosphate emissions to freshwater from and water use in intensive livestock production and grain production but also because both categories went from being very small sources to very small sinks, so the percentage change was large but the actual value of the change was small, as 
Life cycle assessment of Danish pork exports using different cooling technologies and comparison of upstream supply chain efficiencies between Denmark, China and Australia

indicated in Appendix C, Table C.8. Land use and marine eutrophication were the only two categories where the results were worse after the allocation of coproduct impacts.

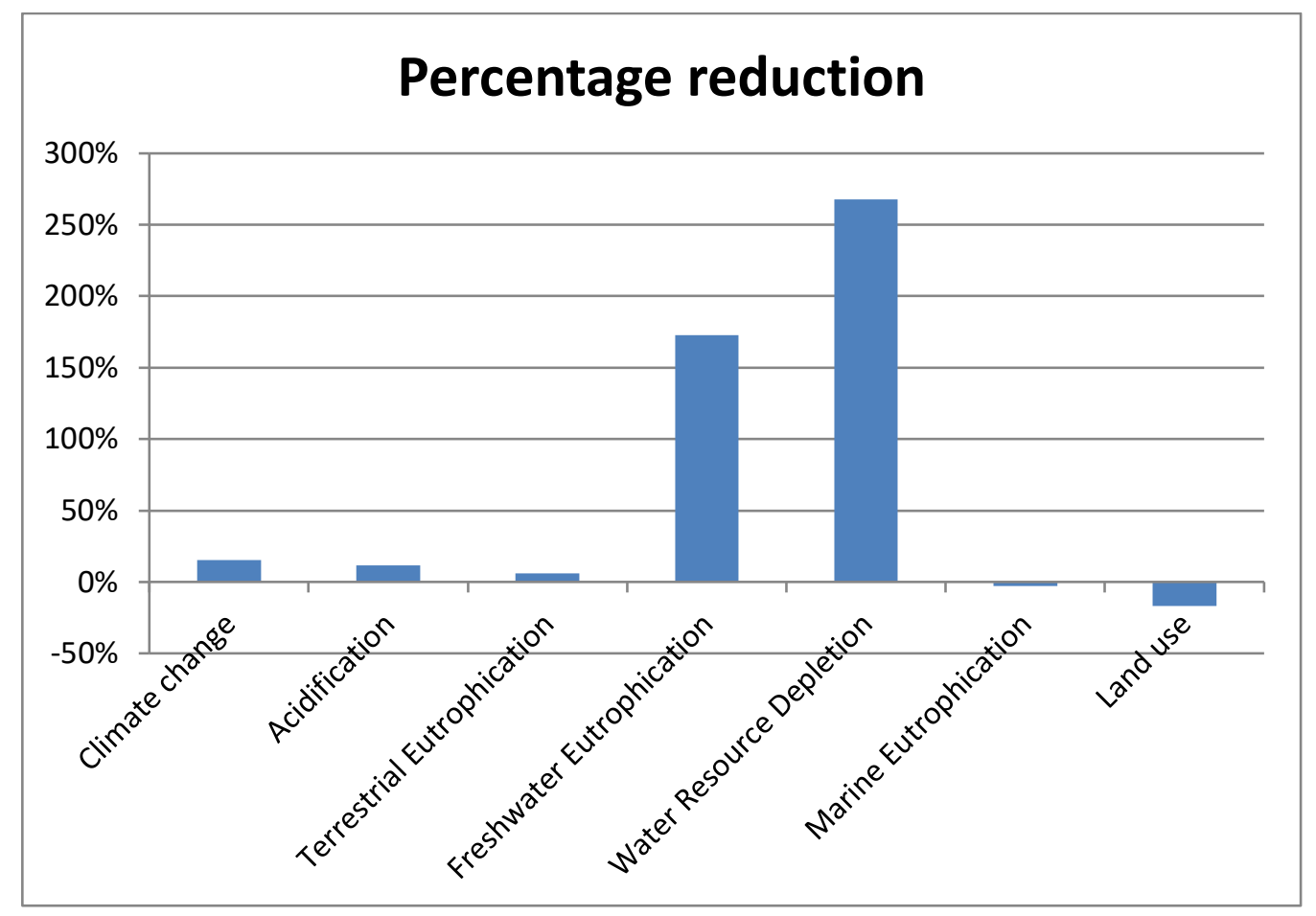

Figure 3: Percentage reduction in impact categories after reallocation of credits

Overall this indicates the relative efficiency of pork production compared to other meat alternatives in the impact categories where the results improved after allocation of credits. If the replacement "average" Danish meat had included fish, which provided 35\% of all non-pork animal products consumed in 2014 (compared to 30\% beef and 34\% poultry) (EUROSTAT, 2014) or the weighted average of the "average" meat in the markets receiving exports from Denmark, then the analysis would have yielded different results. However, it is not likely that using a different average meat product would have changed the portion of the supply chain which contributes the most impacts or which technology performs the best at super-chilling.

This analysis does not consider the ultimate sustainability of pork production over other meat products or relative to non-animal protein sources, but rather limits its assessment to how consumer demands for pork can be met with the least environmental impact. Values for HEPR and arable land calculated should enable comparisons with other meat and human edible protein supply chains.

The analysis did not consider consumer preferences in the end markets in terms of fresh, superchilled or frozen products. Similarly, the analysis did not consider loss rates in the receiving markets at the retailer or once the product was purchased by a consumer from a retailer (ie post purchase consumer behaviour), it only considered delivery of the product to the retailer in the final market. Differences within each market would create different loss rates, which would influence the overall assessment.

4. Conclusion \& Further work 
Life cycle assessment of Danish pork exports using different cooling technologies and comparison of upstream supply chain efficiencies between Denmark, China and Australia

This work used the results for a government-funded LCA study to confirm the technical potential of exporting pork from Denmark to distant markets such as China as super-chilled, rather than frozen, products. Further investigation as part of a PhD project into supply chain efficiencies, and analysed the mid-point impact categories of human edible protein required and arable land required, to compare the efficiency of the pork supply chains in Denmark, Australia and China.

The work found that super-chilling is a feasible technology for exporting pork products to distant markets. Of the available super-chilling technologies, chilling rooms, impingement/spiral, and cryogenic have the lowest environmental impact, although the difference between the technologies is not large as indicated in Table 9. The achievable in-plant efficiency of the technologies should be assessed and confirmed rather than relying on theoretical calculations, particularly for the chilling room option. The pork product with the lowest impact was the feet, while ham has the largest impact, but once again, the difference between the products was not significant and could be due, at least in part, to the uncertainty relating to date, the modelling of energy use and the mass allocation used. Given the small differences between the super-chilling technologies, any optimisation will be based on economic rather than environmental impacts. This result reinforces that the upstream (on farm) and downstream (retail-consumer) life cycle stages are more suitable targets for future optimisation efforts.

Some additional work may be required on the consumer or market preferences in the export markets for super-chilled pork as a "fresh" product. As the functional unit relates to delivering the product to the final market, this assessment does not consider loss rates once the product reaches the retailer or end consumer, so this issue may require further research to understand the export pork markets, particularly any limitations associated with the cold chain once products arrive at a destination port that may result in higher loss rates. For example, immersion was the worst performing super-chilling technology, mostly due to the extra packaging required, but the extra packaging may reduce loss rates in the final market.

Given that the additional life cycle stages relating to export contribute $0-1 \%$ of the impact and that Denmark has a higher relative efficiency in terms of HEPR and hectares of arable land required to produce one kilogram of pork, it is likely that pork produced in Denmark will be the better environmentally preferable pork alternative for the foreseeable future. HEPR and arable land use are useful metrics with which to assess supply chain efficiencies.

Ideally, data would be available from industry sources on a regular basis to enable a comparison between supply chain efficiencies on the basis of a total supply chain indicator, such as the arable land area required to produce one kilogram of edible human protein and the HEPR. Alternatively, the data required to calculate these values (namely the whole herd FCR, feed composition, feed country of origin, protein content and crop yield) would be available rather than single indicators at sub-system levels, such as finisher feed conversion ratios or nutrient use efficiencies.

Although the efficiency of pork production in Denmark is higher than China and Australia, the supply chain is a net consumer of human edible protein, as the HEPR is greater than one. As competition for arable land increases as the global human population increases, HEPR could be used to compare all sources of human edible protein and inform policy choices relating to food production. 
Life cycle assessment of Danish pork exports using different cooling technologies and comparison of upstream supply chain efficiencies between Denmark, China and Australia

Acknowledgements: Special thanks to Niels Conradsen from Danish Technological Institute, DMRI for his assistance and endless patience, Jakob Raffn and Teodora Dorca-Preda from Aarhus University and to Dr Rowan O'Hagan and Charles Rikard-Bell at the Australian Pork CRC.

Funding: The LCA portion of the work was supported by the GlobalMeat 2013 project, the arable land/HEPR work was completed as part of a self-funded PhD project at DTU.

\section{References}

Agriculture and Horticulture Development Board, 2018. 2017 Pig cost of production in selected countries. Stoneleigh Park, Kenilworth, Warwickshire. https://doi.org/10.1007/b14140

ASHRAE, 2006. Chapter 9 - Thermal Properties of Food, in: ASHRAE (Ed.), 2006 ASHRAE Handbook Refrigeration. ASHRAE, p. 31.

Bai, Z.H., Ma, L., Qin, W., Chen, Q., Oenema, O., Zhang, F.S., 2014. Changes in Pig Production in China and Their Effects on Nitrogen and Phosphorus Use and Losses. Environ. Sci. Technol. 48, 12742-12749. https://doi.org/10.1021/es502160v

Basset-Mens, C., van der Werf, H.M.G., 2005. Scenario-based environmental assessment of farming systems: the case of pig production in France. Agric. Ecosyst. Environ. 105, 127-144. https://doi.org/10.1016/j.agee.2004.05.007

Beaufort, A., Cardinal, M., Le-Bail, A., Midelet-Bourdin, G., 2009. The effects of superchilled storage at $-2^{\circ} \mathrm{C}$ on the microbiological and organoleptic properties of cold-smoked salmon before retail display. Int. J. Refrig. 32, 1850-1857. https://doi.org/10.1016/j.ijrefrig.2009.07.001

Bogh-Sorensen, L., Zeuthen, P., 1984. The validity of the TTT-concept on the shelf lives of chilled, cured meat products, in: Proceedings of the European Meeting of Meat Research Workers. pp. 30, Section 5:5, pp223-224.

Bonou, A., Birkved, M., 2016. LCA of pork products \& evaluation of alternative super-chilling techniques. Lyngby.

Cassidy, E.S., West, P.C., Gerber, J.S., Foley, J.A., 2013. Redefining agricultural yields: from tonnes to people nourished per hectare. Environ. Res. Lett. 8, 034015. https://doi.org/10.1088/17489326/8/3/034015

Cazemier, L., 2016. The Influence of Trade on The Flow of Nutrients.

Cederberg, C., Wivstad, M., Bergkvist, P., Mattsson, B., Ivarsson, K., 2005. Environmental Assessment of Plant Protection Strategies Using Scenarios for Pig Feed Production. AMBIO A J. Hum. Environ. 34, 408-413. https://doi.org/10.1579/0044-7447-34.4.408

Cheng, H., Wang, You-ming, Meng, Q., Guo, J., Wang, Yi-zheng, 2011. Pork production system and its development in mainland China. Int. J. Fish. Aquac. 3, 166-174.

Dalgaard, R., Halberg, N., Hermansen, J., 2007. Danish pork production: An environmental assessment, DJF Animal Science. Tjele.

Dalgaard, R., Halberg, N., Kristensen, I.S., Larsen, I., 2006. Modelling representative and coherent Danish farm types based on farm accountancy data for use in environmental assessments. Agric. Ecosyst. Environ. 117, 223-237. https://doi.org/10.1016/j.agee.2006.04.002

Dalgaard, R.L., 2007. The environmental impact of pork production from a life cycle perspective. 
Life cycle assessment of Danish pork exports using different cooling technologies and comparison of upstream supply chain efficiencies between Denmark, China and Australia

Aalborg \& Aarhus.

Danish Agriculture \& Food Council, 2018. Statistics 2017 - Pigmeat - June 2018. Copenhagen.

Danish Agriculture \& Food Council, 2017. Statistics 2016 - Pigmeat - June 2017. Copenhagen.

Danish Agriculture \& Food Council, 2016. Statistics 2015. Copenhagen.

Danish Pig Research Centre (SEGES), 2016. Annual Report 2015. Copenhagen.

DMRI, 2016. Shelf Life Model [WWW Document]. URL http://dmripredict.dk/Models/ShelfLife/ (accessed 11.22.16).

DTU, 2016. Fooddata (Food database) [WWW Document]. Natl. Food Inst. -Food database. URL http://frida.fooddata.dk/index.php?lang=en. (accessed 11.30.16).

DTU Food (National Food Institute), 2019. Rice bran composition [WWW Document]. Frida fooddata.dk. URL https://frida.fooddata.dk/food/1081?lang=en (accessed 2.27.19).

Duun, A.S., Hemmingsen, A.K.T., Haugland, A., Rustad, T., 2008. Quality changes during superchilled storage of pork roast. LWT - Food Sci. Technol. 41, 2136-2143. https://doi.org/10.1016/j.Iwt.2008.02.001

EC-JRC, 2010. (ILCD) Handbook: General guide for Life Cycle Assessment - Detailed guidance. Luxembourg. https://doi.org/10.2788/38479

Environmental Protection Agency, 2017. Overview of the Danish regulation of nutrients in agriculture and the Danish Nitrates Action Programme 2017. Copenhagen.

European Commission, 2005. Integrated Pollution Prevention and Control - BAT in Slaughterhouses and Animal By-product Industries. European Commission.

EUROSTAT, 2014. Statistics on slaughtering, all species, by country, 2014 [WWW Document]. Stat. Explain. URL http://ec.europa.eu/eurostat/statisticsexplained/index.php/File:Statistics_on_slaughtering,_all_species,_by_country,_2014.png. (accessed 11.22.16).

FAO, 2017. FAOSTAT website [WWW Document]. URL http://www.fao.org/faostat/en/\#data

Gale, F., 2017. China's Pork Imports Rise Along with Production Costs, LDPM-271-01, United States Department of Agriculture.

Hamann, K., 2006. An Overview of Danish Pork Industry Integration and Structure. Adv. Pork Prod. $17,93-97$.

Haugland, A., Aune, E. J. Hemmingsen, A.K.T., 2005. Superchilling - innovative processing of fresh food., in: EuroFreeze 2005: Individual Quick Freezing of Foods, Proceedings of EU Workshop (Project QLK1-CT-2002-30544), 13-15 January 2005. Sofia, Bulgaria, pp. pp1-8.

Hededal Hofer, L., 2016. Contact with Louise Hededal Hofer from Danish Technological Institute, DMRI.

Hydro Tasmania Consulting, 2009. Red Meat Processing Industry Energy Efficiency Manual (A.ENV.0065). North Sydney.

James, S.J., 2002. New developments in the chilling and freezing of meat, in: Kerry, J.P., Kerry, J.F., 
Life cycle assessment of Danish pork exports using different cooling technologies and comparison of upstream supply chain efficiencies between Denmark, China and Australia

Ledward, D.A. (Eds.), Meat Processing: Improving Quality. Woodhead Publishing Series in Food Science, Technology and Nutrition, pp. 297-312.

James, S.J., James, C., 2011. Impact of refrigeration on processed meat safety and quality, in:

Processed Meats: Improving Safety, Nutrition and Quality. Woodhead Publishing Limited, Cambridge, UK, pp. 567-589. https://doi.org/10.1533/9780857092946.3.567

Ledgard, S.F., Lieffering, M., Coup, D., O'Brien, B., 2011. Carbon footprinting of New Zealand lamb from the perspective of an exporting nation. Anim. Front. 1, 40-45. https://doi.org/10.2527/af.2011-0010

Lee, P., Osborn, S., Whitehead, P., 2015. Reducing food waste by extending product life.

Magnussen, O.M., Haugland, A., Torstveit Hemmingsen, A.K., Johansen, S., Nordtvedt, T.S., 2008. Advances in superchilling of food - Process characteristics and product quality. Trends Food Sci. Technol. 19, 418-424. https://doi.org/10.1016/j.tifs.2008.04.005

McAuliffe, G.A., Chapman, D. V., Sage, C.L., 2016. A thematic review of life cycle assessment (LCA) applied to pig production. Environ. Impact Assess. Rev. 56, 12-22. https://doi.org/10.1016/j.eiar.2015.08.008

McMillin, K.W., Belcher, J.N., 2012. Advances in Meat, Poultry and Seafood Packaging, Advances in Meat, Poultry and Seafood Packaging. Elsevier. https://doi.org/10.1533/9780857095718.2.171

Mogensen, L., Trydeman Knudsen, M., Dorca-Preda, T., Ingemann Nielsen, N., Sillebak Kristensen, I., Kristensen, T., 2018. BAEREDYGTIGHEDSPARAMETRE FOR KONVENTIONELLE FODERMIDLER TIL KVAEG-METODE OG TABELVAERDIER DCA RAPPORT NR. 116 (in Danish). Aarhus.

NASA Earth Observatory, 2009. Drought in Argentina [WWW Document]. URL https://earthobservatory.nasa.gov/images/37105/drought-in-argentina (accessed 2.19.19).

Nersting, L., 2016. Meetings and contact with Lise Nersting from Danish Technological Institute, DMRI.

Nguyen, T.L.T., Hermansen, J.E., Mogensen, L., 2011. Environmental Assessment of Danish Pork, Report No. 103. Tjele.

Notteboom, T., Cariou, T., 2009. Fuel surcharge practices of container shipping lines: Is it about cost recovery or revenue making, in: Proceedings of the 2009 International Association of Maritime Economists (IAME) Conference. Copenhagen. Copenhagen, p. pp 24-26.

Noya, I., Villanueva-Rey, P., González-García, S., Fernandez, M.D., Rodriguez, M.R., Moreira, M.T., 2017. Life Cycle Assessment of pig production: A case study in Galicia. J. Clean. Prod. 142. https://doi.org/10.1016/j.jclepro.2016.11.160

Olafsdottir, G., Lauzon, H.L., Martinsdottir, E., Oehlenschlager, J., Kristberg, K., 2006. Evaluation of Shelf Life of Superchilled Cod (Gadus morhua) Fillets and the Influence of Temperature Fluctuations During Storage on Microbial and Chemical Quality Indicators. J. Food Sci. 71, 97109. https://doi.org/10.1111/j.1365-2621.2006.tb08928.x

Ontaria Ministry of Agriculture Food and Rural Affairs, 2012. Comparative Feed Values for Swine [WWW Document]. Factsheet 03-003. URL

http://www.omafra.gov.on.ca/english/livestock/swine/facts/03-003.htm\#protein

Reckmann, K., Traulsen, I., Krieter, J., 2013. Life Cycle Assessment of pork production: A data 
Life cycle assessment of Danish pork exports using different cooling technologies and comparison of upstream supply chain efficiencies between Denmark, China and Australia

inventory for the case of Germany. Livest. Sci. 157, 586-596.

https://doi.org/10.1016/j.livsci.2013.09.001

Scheller Andersen, J., 2016. Meetings and contact with Jens Scheller Andersen from Danish Technological Institute, DMRI.

Sea-distances.org, 2016. Sea distances. [WWW Document].

SEGES Svineproduktion, 2018. SEGES Feed Table (excel spreadsheet in Danish) [WWW Document]. SEGES Foderm. Tab. (Feed Table). URL https://svineproduktion.dk/Viden/Paakontoret/Oekonomi_ledelse/Beregningsvaerktoejer/Fodervaerktoejer (accessed 2.20.19).

Sofos, J.N., 2005. Improving the safety of fresh meat, Woodhead P. ed. Woodhead Publishing Limited.

Statistics Denmark, 2016. Denmark in figures 2016. Copenhagen.

Thy, C., 2016. Contact with Charlotte Thy from Danish Crown.

USDA, 2016. Food Composition Database [WWW Document]. USDA -Agricultural Res. Serv.

USDA Foreign Agricultural Service, 2018a. Livestock and Products Semi-annual - Consolidation and Modernization Continue to Shape China's Livestock Outlook (GAIN Report Number: CH 18016).

USDA Foreign Agricultural Service, 2018b. Peoples Republic of China - Grain and Feed Update Drought, Floods and Storms Buffet China's Grain Market (GAIN Report Number: CH 18039).

USDA Foreign Agricultural Service, 2018c. Peoples Republic of China - Oilseeds and Products Annual (GAIN Report Number CH 18012).

USDA Foreign Agricultural Service, 2018d. Grain: World Markets and Trade - Commodities and Data (December 2018).

USDA Foreign Agricultural Service, 2009. China Drought April 2009 [WWW Document]. Commod. Intell. Rep. - CHina 2009-2010 Winter Wheat Situat. URL https://ipad.fas.usda.gov/highlights/2009/04/ChinaDrought/ (accessed 2.19.19).

Van Zanten, H.H.E., Mollenhorst, H., Klootwijk, C.W., Van Middelaar, C.E., Imke, \&, De Boer, J.M., 2016. LCA OF NUTRITION AND FOOD CONSUMPTION Global food supply: land use efficiency of livestock systems. Int. J. Life Cycle Assess. 21, 747-758. https://doi.org/10.1007/s11367-0150944-1

Verge, X., Worth, D.E., Dyer, J.A., Desjardins, R.L., Mcconkey, B.G., 2012. Chapter 4 : LCA of Animal Production, in: Green Technologies in Food Production and Processing. Springer US, pp. 1-31.

Verheijen, L.A.H.M., Wiersema, D., Hulshoff Pol, L.W., 1996. Management of Waste from Animal Product Processing. Wageningen, The Netherlands.

Wiedemann, S.G., 2018. Analysis of Resource Use and Greenhouse Gas Emissions from Four Australian Meat production systems, with investigation of mitigation opportunities and tradeoffs. Charles Sturt.

Wiedemann, S.G., McGahan, E., Murphy, C., Yan, M.-J., Henry, B., Thoma, G., Ledgard, S., 2015. Environmental impacts and resource use of Australian beef and lamb exported to the USA determined using life cycle assessment. J. Clean. Prod. 94, 67-75.

https://doi.org/10.1016/j.jclepro.2015.01.073 
Life cycle assessment of Danish pork exports using different cooling technologies and comparison of upstream supply chain efficiencies between Denmark, China and Australia

Wiedemann, S.G., McGahan, E.J., Murphy, C.M., 2018. Environmental impacts and resource use from Australian pork production determined using life cycle assessment. 2. Energy, water and land occupation. Anim. Prod. Sci. 58, 1153. https://doi.org/10.1071/AN16196

Wiedemann, S.G., McGahan, E.J., Murphy, C.M., 2017. Environmental impacts and resource use from Australian pork production determined using life cycle assessment. 2. Energy, water and land occupation. Anim. Prod. Sci. 58, 1153. https://doi.org/10.1071/AN16196

Wiedemann, S.G., McGahan, E.J., Murphy, C.M., 2016. Environmental impacts and resource use from Australian pork production assessed using life-cycle assessment . 1. Greenhouse gas emissions. Anim. Prod. Sci. 56, 1418-1431.

Wiedemann, S.G., Yan, M.-J., 2014. Livestock meat processing: inventory data and methods for handling co-production for major livestock species and meat products, in: Schenck, R., Huizenga, D. (Eds.), Proceedings of the 9th International Conference on Life Cycle Assessment in the Agri-Food Sector (LCA Food 2014). ACLCA, Vashon, WA, USA, San Francisco, p. 11.

Worldshipping.org, 2016. Top 50 world container ports [WWW Document]. URL http://www.worldshipping.org/about-the-industry/global-trade/top-50-world-container-ports (accessed 11.22.16).

Zhou, G.H., Xu, X.L., Liu, Y., 2010. Preservation technologies for fresh meat - A review. Meat Sci. 86, 119-128. https://doi.org/10.1016/j.meatsci.2010.04.033

Zhou, Y.Q., Dong, H.M., Xin, H.W., Zhu, Z.Z., Huang, W.Q., Wang, Y., 2018. Carbon Footprint Assessment of a Large-Scale Pig Production System in Northern China: A Case Study. Trans. Am. Soc. Agric. Biol. Eng. 61, 1121-1131. 
Life cycle assessment of Danish pork exports using different cooling technologies and comparison of upstream supply chain efficiencies between Denmark, China and Australia

Appendices

Appendix A - Detailed information for LCA modelling

Table A.1: Product specifications and calculated specific heat capacities of the assessed pork products. The energy and content has been based on Danish and U.S. food databases (DTU 2016; USDA 2016).

\begin{tabular}{|c|c|c|c|c|c|c|c|c|}
\hline & $\begin{array}{c}\text { Weight } \\
\mathrm{kg} / \mathrm{pig}\end{array}$ & $\begin{array}{c}\mathrm{kcal} / \\
100 \mathrm{~g}\end{array}$ & $\begin{array}{c}\text { Fat } \\
\%\end{array}$ & $\begin{array}{c}\text { Protein } \\
\%\end{array}$ & $\begin{array}{c}\text { Ash } \\
\%\end{array}$ & $\begin{array}{c}\text { Water } \\
\%\end{array}$ & $\begin{array}{c}\text { Specific heat above } \\
\text { freezing (kJ/kg K) }\end{array}$ & $\begin{array}{c}\text { Specific heat below } \\
\text { freezing (kJ/kg K) }\end{array}$ \\
\hline Tender Loin & 1.275 & 119 & 3.8 & 20.9 & 1.2 & 74.1 & 3.57 & 2.97 \\
\hline Neck bone & 1.185 & & & & & & 3.20 & 2.36 \\
\hline Rib bones & 0.573 & 275 & 23.4 & 15.67 & 0.69 & 58.43 & 3.20 & 2.36 \\
\hline Minced meat & 6 & 173 & 11.2 & 18.4 & 1 & 69.4 & 3.47 & 2.58 \\
\hline Whole ham & 15.74 & 165 & 2 & 20.7 & 0.9 & 60.8 & 2.98 & 2.40 \\
\hline Belly (for Bacon) & 7.871 & 518 & 53.01 & 9.34 & & 36.74 & 2.76 & 1.90 \\
\hline Tongue & 0.243 & 225 & 13.27 & 17.00 & 0.94 & 68.30 & 3.44 & 2.56 \\
\hline Heart & 0.324 & 118 & 1.63 & 17.69 & 1.1 & 79.29 & 3.67 & 2.79 \\
\hline Front feet & 0.842 & 212 & 12.59 & 23.16 & $0.8 * *$ & 64.99 & 3.41 & 2.49 \\
\hline
\end{tabular}

Table A.2: Electricity requirements for the technologies under assessment $(\mathrm{kJ} / \mathrm{kg})$

\begin{tabular}{|l|c|c|c|c|}
\hline & \multicolumn{3}{|c|}{ Cooling method } \\
\cline { 2 - 5 } & $\begin{array}{c}\text { Jet-stream (Impingement NH3) } \\
\text { Spiral (COP 2.6) }\end{array}$ & $\begin{array}{c}\text { Immersion // Contact // } \\
\text { Chilling room (COP 3.7) }\end{array}$ & $\begin{array}{c}\text { Cryogenic } \\
\text { (COP 1) }\end{array}$ & $\begin{array}{c}\text { Freezing } \\
\text { (COP 3.7) }\end{array}$ \\
\hline Tender Loin & 8.24 & 5.79 & 21.42 & 20.07 \\
\hline Neck bone & 7.39 & 5.19 & 19.2 & 15.95 \\
\hline Rib bones & 7.39 & 5.19 & 19.2 & 15.95 \\
\hline Minced meat & 8.01 & 5.63 & 20.82 & 17.43 \\
\hline Whole ham & 6.87 & 4.83 & 17.88 & 16.22 \\
\hline Belly (for Bacon) & 6.37 & 4.48 & 16.56 & 12.84 \\
\hline Tongue & 7.93 & 5.57 & 20.64 & 17.30 \\
\hline Heart & 8.48 & 5.96 & 22.02 & 18.85 \\
\hline Front feet & 7.87 & 5.53 & 20.46 & 16.82 \\
\hline
\end{tabular}

Note: 1) based on the sublimation energy of R477

Table A.3: Detailed information relating to specific process areas

\begin{tabular}{|c|c|}
\hline Issue & Detail or assumption \\
\hline Assessment & $\begin{array}{l}\text { - Attributional, mass allocation of impacts, system expansion to handle multi- } \\
\text { functionality with upstream substitution } \\
\text { - Software SimaPro v8.1, Ecoinvent database v3.01 } \\
\text { - System boundary: from the farm to the consumer } \\
\text { - Functional unit: } 1 \mathrm{~kg} \text { of pork product unpacked at the consumer }\end{array}$ \\
\hline Animal raising & $\begin{array}{l}\text { - } \text { Based on average pig raising for the average Danish Landrace pig breed } \\
\text { - Manure/slurry is digested anaerobically and biogas generated is used to } \\
\text { replace fossil fuels } \\
\text { - Inventory taken from Nguyen et al. 2011, Table 1, Baseline: typical } 2010 \\
\text { production, Attributional PAS } 2050 \text { data } \\
\text { - Live weight of fattened pigs sent to meat processing plant is } 100 \mathrm{~kg} \text {, but } \\
\text { average weight of live animals received at meat processing plant is higher } \\
\text { depending on how many surplus breeder sows are received in the given } \\
\text { reporting period }\end{array}$ \\
\hline
\end{tabular}


Life cycle assessment of Danish pork exports using different cooling technologies and comparison of upstream supply chain efficiencies between Denmark, China and Australia

\begin{tabular}{|c|c|}
\hline Issue & Detail or assumption \\
\hline $\begin{array}{l}\text { Transport to } \\
\text { meat } \\
\text { processing }\end{array}$ & $\begin{array}{l}\text { - Assumed to be } 240 \mathrm{~km} \text { from farm to meat processing plant } \\
\text { - Meat processing plant located at Horsens in Denmark was used }\end{array}$ \\
\hline $\begin{array}{l}\text { Meat } \\
\text { processing }\end{array}$ & $\begin{array}{l}\text { - Average live weight at start of meat processing is } 104 \mathrm{~kg} \\
\text { - The black slaughter line removes blood and hair/bristles/toenails from } \\
\text { carcase, weight of carcase leaving line is } 99 \mathrm{~kg} \text { (based on data from DMRI } \\
\text { that } 4.5 \% \text { of live weight lost in black slaughter line) } \\
\text { - The clean slaughter line workers remove intestines, internal organs and front } \\
\text { feet and the carcase is split into two. Weight of hot standard carcase leaving } \\
\text { line is } 79 \mathrm{~kg} \text { (HSCW) based on } 76 \% \text { yield live weight to hot standard carcase } \\
\text { weight (DMRI). } \\
\text { - Chilling reduces the carcase temperature to } 5^{\circ} \mathrm{C} \text { during a residence time of } \\
110 \text { minutes in a chilling tunnel using air at }-16^{\circ} \mathrm{C} \text { and then } 16 \text { hours in an } \\
\text { equalisation room at } 5^{\circ} \mathrm{C} \text {. This results in evaporative loss of approximately } 1 \\
\text { kg water (EU maximum of } 2 \% \text { weight loss in chillers), weight of dry carcase } \\
\text { leaving equalisation room is } 78 \text { kg (DCW), assumes } 1.3 \% \text { HSCW water loss in } \\
\text { chillers (i.e. } 1 \text { kg). } \\
\text { Cutting stage involves partial head removal, automated trisection (into } \\
\text { shoulders, middle and hams), grading, further automated cutting of middle } \\
\text { piece (into loin and streaky bacon), further trimming of hams (and tail } \\
\text { removal) and shoulder (removal of remainder of head) and hanging of } \\
\text { trimmed shoulders, middle parts (loin and streaky bacon) and trimmed hams } \\
\text { onto storage equipment (“Christmas trees”). Combined weight of pork } \\
\text { leaving cutting stage for deboning depends on customer requirements. } \\
\text { Deboning stage involves removal of bones from streaky bacon and other } \\
\text { cuts, depending on customer requirements } \\
\text { Packaging of products uses either boxes for the retail sector, or Christmas } \\
\text { trees and product bins for cuts being sent for further processing by Danish } \\
\text { Crown or external customers. } \\
\text { Further processing may involve brine injection/immersion, cooking, smoking, } \\
\text { etc., depending on customer requirements } \\
\text { Water loss from live weight to retail including drip loss is assumed to be } 7 \% \\
\text { of human edible products }\end{array}$ \\
\hline $\begin{array}{l}\text { Mass } \\
\text { allocation }\end{array}$ & $\begin{array}{l}\text { - Clean slaughter line/Cleaning/Boiler/Ventilation/Evaporative cooling/ } \\
\text { Others/ Energy recovery/ Waste water - uses mass of each product divided } \\
\text { by total live weight (104 kg) minus total water loss }(6.1 \mathrm{~kg}) \text { for each of the } 9 \\
\text { products under study. Remaining mass is split between other edible and } \\
\text { inedible categories based on their respective mass fraction of the total } \\
\text { amount (e.g. other edible = remaining mass } \times 47 /(47+16)) \\
\text { - Organ processing/byproducts - uses the same mass allocation for tongue } \\
\text { and heart as clean slaughter line. Remaining mass is split between minced } \\
\text { meat, other edible and inedible based on their respective mass fraction of } \\
\text { the total amount } \\
\text { Chilling/Cutting/Deboning - for loin, neck bone, ribs, ham and belly, uses } \\
\text { same mass allocation as clean slaughter line. Remaining mass is split } \\
\text { between minced meat, other edible and inedible based on their respective } \\
\text { mass fraction of the total amount }\end{array}$ \\
\hline
\end{tabular}


Life cycle assessment of Danish pork exports using different cooling technologies and comparison of upstream supply chain efficiencies between Denmark, China and Australia

\begin{tabular}{|c|c|}
\hline Issue & Detail or assumption \\
\hline Ham cooking & $\begin{array}{l}\text { - } 7-8 \mathrm{~kg} \text { of whole ham is used for producing processed ham (Nersting, 2016) } \\
\text { - Raw ham goes through curing process where brine solution is directly } \\
\text { injected into muscle tissue and accounts for } 30 \% \text { of final product weight } \\
\text { - Brine composition based on DMRI data (Nersting, 2016) - 80.28\% water, } \\
5.63 \% \text { sodium chloride, } 3.9 \% \text { sodium nitrate, } 8.7 \% \text { dextrose, } 0.2 \% \text { sodium } \\
\text { ascorbate (all percentages are weight) } \\
\text { - Cured meat cooked at } 75{ }^{\circ} \mathrm{C} \text {, cools to } 40{ }^{\circ} \mathrm{C} \text { using spray chilling (water at } 2-3 \\
{ }^{\circ} \mathrm{C} \text { sprayed for } 30-90 \text { seconds at } 15-30 \text { minute intervals (Sofos, } 2005 \text { ), } \\
\text { estimated } 10 \% \text { weight loss (Nersting, } 2016 \text { ). After cooling to } 40{ }^{\circ} \mathrm{C} \text { product is } \\
\text { put into chilling room to reduce the temperature to } 5^{\circ} \mathrm{C}\end{array}$ \\
\hline $\begin{array}{l}\text { Super-chilling } \\
\text { technologies }\end{array}$ & $\begin{array}{l}\text { Existing super-chilling technologies currently used in industry } \\
\text { - Impingement - an air-based, radiant cooling system, where high velocity air } \\
\text { jets are directed at the top and bottom surfaces of the pork product, the } \\
\text { boundary layer at the meat surface is disturbed and heat exchange becomes } \\
\text { more effective, with the resulting time required to freeze the product being } \\
\text { similar to cryogenic freezing } \\
\text { - Spiral - an air-based, convection cooling system, where product is on a spiral } \\
\text { conveyor, and the movement of chilled air removes heat from the product. } \\
\text { - Chilling room - an air-based, convention cooling system, where a continual } \\
\text { movement of chilled air removes heat from the product } \\
\text { - Cryogenic - a carbon dioxide-based, convection cooling system, where dry } \\
\text { carbon-dioxide ice is used to cool the product and the high surface heat } \\
\text { transfer coefficients mean that the cooling rates are higher than other } \\
\text { systems } \\
\text { New super-chilling technologies laboratory tested in this study } \\
\text { - Immersion - a liquid-based convection cooling system, where wrapped meat } \\
\text { is immersed in a tank of cooled liquid. Requires extra packaging material for } \\
\text { the meat product. } \\
\text { Contact - a conduction cooling system, where there is physical contact } \\
\text { between the meat product and a conducting medium (such as metal plates), } \\
\text { and the conducting medium is cooled using a cooling medium such as a fluid } \\
\text { or refrigerant. Difficult to apply to irregularly shaped meat cuts such as feet } \\
\text { (trotters). }\end{array}$ \\
\hline $\begin{array}{l}\text { Wastewater } \\
\text { emissions }\end{array}$ & $\begin{array}{l}\text { - modelled using secondary data from the FAO (Verheijen et al., 1996), which } \\
\text { indicates that } 2.4 \mathrm{~kg} \mathrm{BOD} \text { and } 0.6 \mathrm{~kg} \mathrm{~N} \mathrm{~N}_{\mathrm{kj}} \text { (Kjeldahl nitrogen) are emitted to the } \\
\text { wastewater system per tonne of carcase. }\end{array}$ \\
\hline $\begin{array}{l}\text { Biogas } \\
\text { production }\end{array}$ & $\begin{array}{l}\text { - } 2 \% \text { of live weight as fat used in biogas production, fat heating value of } 38 \\
\mathrm{MJ} / \mathrm{kg} \text { and natural gas heating value of } 49 \mathrm{MJ} / \mathrm{kg}, 1 \mathrm{~kg} \text { of fat corresponds to } \\
0.78 \mathrm{~kg} \text { natural gas }\end{array}$ \\
\hline Transport & $\begin{array}{l}\text { - By road to market }-267 \mathrm{~km} \text { from Horsens plant to Copenhagen used as } \\
\text { default road transport distance for all markets } \\
\text { - By road to port }-52 \mathrm{~km} \text { from Horsens plant to Aarhus port } \\
\text { - By ship to China }-11,052-17,773 \mathrm{~km} \\
\text { - By ship to Australia }-11,638-13,888 \mathrm{~km}\end{array}$ \\
\hline
\end{tabular}

Table A.4: Mass based allocation factors for allocating inputs and impacts to products, coproducts (human edible) and byproducts (human inedible) 
Life cycle assessment of Danish pork exports using different cooling technologies and comparison of upstream supply chain efficiencies between Denmark, China and Australia

\begin{tabular}{|c|c|c|c|c|c|c|c|c|c|c|c|c|}
\hline & 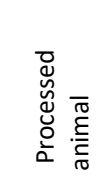 & 호ำ & $\begin{array}{l}0 \\
\text { ¿ } \\
\text { O } \\
\text { i } \\
\text { d }\end{array}$ & $\stackrel{n}{\underline{\alpha}}$ & $\begin{array}{l}\frac{\varepsilon}{\pi} \\
\frac{\pi}{I}\end{array}$ & $\stackrel{\bar{\Phi}}{\bar{\Phi}}$ & 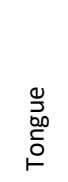 & $\begin{array}{l}\frac{t}{\pi} \\
\stackrel{\Xi}{I} \\
\text { I. }\end{array}$ & 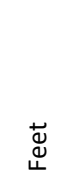 & 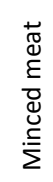 & 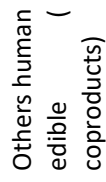 & 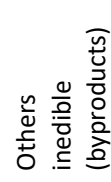 \\
\hline Cut weight (kg) & & 1.28 & 1.19 & 0.57 & 15.7 & 7.78 & 0.24 & 0.32 & 0.84 & 6.0 & 47.8 & 16 \\
\hline & $\begin{array}{l}\text { Animal } \\
\text { weight }\end{array}$ & \multicolumn{11}{|c|}{ \% allocation based on each cut's proportion of the animal weight going through each process } \\
\hline $\begin{array}{l}\text { - Farming } \\
\text { - Transport from farm } \\
\text { - Washing area } \\
\text { - Black slaughter line } \\
\text { - Cleaning } \\
\text { - Heating } \\
\text { - Ventilation } \\
\text { - Evaporative cooling } \\
\text { - Others } \\
\text { - Energy recovery } \\
\text { - Wastewater }\end{array}$ & 104 & 1.3 & 1.2 & 0.6 & 16.1 & 8 & 0.2 & 0.3 & 0.9 & 6.1 & 48.9 & 16.3 \\
\hline Clean slaughter line & 99 & 1.4 & 1.3 & 0.6 & 16.9 & 8.5 & 0.3 & 0.3 & 0.9 & 6.5 & 47.5 & 15.9 \\
\hline Chilling & 79 & 1.7 & 1.6 & 0.8 & 21.6 & 10.8 & - & - & - & 5.5 & 43.5 & 14.5 \\
\hline Cutting/ Deboning & 78 & 1.8 & 1.6 & 0.8 & 21.9 & 10.9 & - & - & - & 5.4 & 43.1 & 14.4 \\
\hline $\begin{array}{l}\text { Organ processing/ } \\
\text { by-product production }\end{array}$ & 25 & - & - & - & - & - & 1 & 1.3 & - & 8.4 & 66.9 & 22.4 \\
\hline
\end{tabular}

Table A.5: Average meat composition for Denmark, 2014 (EUROSTAT, 2014)

\begin{tabular}{|l|c|c|}
\hline Animal & $\begin{array}{c}\text { Total weight slaughtered (1000 } \\
\text { tonnes) }\end{array}$ & $\begin{array}{c}\text { Average animal (excluding } \\
\text { pigs) }\end{array}$ \\
\hline Pork (porcine) & 1,587 & $46 \%$ \\
\hline Beef (bovine) & 126 & $53 \%$ \\
\hline Chicken (galline) & 143 & $1 \%$ \\
\hline Sheep (ovine) & 2 & \\
\hline
\end{tabular}

Generic life cycle inventory data for the global market for cattle, chicken and sheep slaughtering from the Ecoinvent database was used for the substituted meat products. So for example, the credit from feed was calculated by multiplying the mass percentage of live weight (7.5\%) by the percentage of each of the other meat categories, to give the allocation keys in Table .

Table A.6: Allocations keys for substituting 'average meat' byproducts

\begin{tabular}{|l|c|c|c|c|}
\hline Secondary functions & $\begin{array}{c}\text { \% live } \\
\text { weight }\end{array}$ & \multicolumn{2}{|c|}{$\begin{array}{c}\text { Allocation factors for assigning impacts to the corresponding functions of the } \\
\text { average meat }\end{array}$} \\
\hline & & Bovine & Ovine & Galline \\
\hline Feed & 7.5 & $3.5 \%$ & $0.1 \%$ & $0.0 \%$ \\
\hline Pharma & 0.2 & $0.1 \%$ & $0.1 \%$ & $3.8 \%$ \\
\hline Rendering & 7.2 & $3.3 \%$ & $\begin{array}{l}\text { Substitute for natural gas. Assumed heating values for fat: } 38 \mathrm{MJ} / \mathrm{kg} \text {. For natural } \\
\text { gas 49 MJ/kg. 1 kg of fat corresponds to 0.78 kg natural gas }\end{array}$ \\
\hline Fat for biogas & 2 & \multicolumn{3}{|l}{}
\end{tabular}

These were then included in the modelling as negative flows, so 
Life cycle assessment of Danish pork exports using different cooling technologies and comparison of upstream supply chain efficiencies between Denmark, China and Australia

avoided feed $=(104 \mathrm{~kg}$ live weight $*-0.035 *$ market for cattle for slaughtering $)$

$+(104 \mathrm{~kg}$ live weight $*-0.001 *$ market for sheep for slaughtering $)$

$+(104 \mathrm{~kg}$ live weight $*-0.04 *$ market for chicken slaughtering $)$ 
Life cycle assessment of Danish pork exports using different cooling technologies and comparison of upstream supply chain efficiencies between Denmark, China and Australia

Appendix B - Detailed data used in HEPR and arable land calculations

Table B.1: Detailed information on Australian feed derived from published literature

\begin{tabular}{|c|c|c|c|c|c|c|c|c|c|}
\hline & \multicolumn{3}{|c|}{ National Herd average } & \multirow{2}{*}{$\begin{array}{l}\text { Whole } \\
\text { herd } \\
\text { FCR }^{1}\end{array}$} & \multirow{2}{*}{$\begin{array}{c}\text { Mass } \\
\%\end{array}$} & \multirow{2}{*}{$\begin{array}{l}\text { Average } \\
\text { protein }\end{array}$} & \multirow{2}{*}{$\begin{array}{l}\text { Economic } \\
\text { allocation }\end{array}$} & \multirow{2}{*}{ Feed origin } & \multirow{2}{*}{$\begin{array}{c}\text { Yield } \\
\left(\mathrm{kg} / \mathrm{m}^{2}\right) \\
\text { base case-2016/ } \text { lowest }^{4}\end{array}$} \\
\hline $\begin{array}{r}\text { Ratio component } \\
(\mathrm{kg})\end{array}$ & Breeder $^{1}$ & Weaner $^{1}$ & $\begin{array}{l}\text { Grower- } \\
\text { Finisher }^{1}\end{array}$ & & & & & & \\
\hline Barley & 349.01 & 105.77 & 230.73 & 0.70 & 22 & $11 \%$ & $99 \%^{2}$ & \multirow{2}{*}{$\begin{array}{l}100 \% \text { Australia, same } \\
\% \text { per region assumed } \\
\text { as pork production }\end{array}$} & $0.16^{1} / 0.15$ \\
\hline Wheat & 383.83 & 628.43 & 460.06 & 1.65 & 53 & $12 \%$ & $95 \%^{2}$ & & $0.16^{1} / 0.11$ \\
\hline Sorghum & 85.49 & 57.39 & 124.20 & 0.35 & 11 & $11 \%$ & $60 \%^{3}$ & \multirow{4}{*}{$100 \%$ Australian } & $0.34^{4} / 0.24$ \\
\hline Lupins & 19.10 & 11.40 & 22.80 & 0.07 & 2 & $34 \%$ & $100 \%^{3}$ & & $0.12^{4} / 0.09$ \\
\hline Field peas & 27.81 & 16.60 & 33.20 & 0.10 & 3 & $20.5 \%$ & $100 \%^{3}$ & & $0.57^{4} / 0.44$ \\
\hline Canola meal & 39.97 & 47.34 & 53.97 & 0.17 & 6 & $34 \%$ & $28 \%^{5}$ & & $0.13^{4} / 0.10$ \\
\hline Soymeal & 15.10 & 24.07 & 10.00 & 0.05 & 1 & $48 \%$ & $62 \%^{5}$ & $\begin{array}{l}5 \% \text { Australian, } 18 \% \\
\text { USA, } 39 \% \text { Brazil, } 38 \% \\
\text { Argentina }^{5}\end{array}$ & $\begin{array}{c}2016^{4}-\mathrm{AU}=0.213, \mathrm{USA}= \\
0.3494, \text { Brazil }=0.2905 \\
\text { Argentina }=0.3015 \\
\text { Lowest }-0.18, \text { Argentina, } 2009\end{array}$ \\
\hline Veg oil (canola) & 10.52 & 13.54 & 3.92 & 0.02 & 1 & $0 \%$ & $72 \%^{5}$ & & \\
\hline Crude protein & $14.38 \%^{5}$ & $18.72 \%^{5}$ & $16.48 \%^{5}$ & $14.1 \%$ & \multicolumn{5}{|c|}{$\begin{array}{l}\text { 13.8\% average protein from (Wiedemann, 2018) } \\
14.1 \% \text { average protein calculated using data provided }\end{array}$} \\
\hline Total & 945.20 & 923.25 & 955.36 & & \multirow{3}{*}{\multicolumn{5}{|c|}{$\begin{array}{l}16.10 \mathrm{~m}^{2} \text { arable land from Wiedemann, } 2018 \\
16.11 \mathrm{~m}^{2} \text { arable land calculated using data provided and assumed economic allocation } \\
\text { factors }\end{array}$}} \\
\hline $\begin{array}{r}\text { Weight gain } \\
\text { (kg per live pig) }\end{array}$ & 7 & 23 & 67.4 & 97.4 & & & & & \\
\hline $\begin{array}{l}\text { Whole herd FCR } \\
\mathrm{kg} \text { feed / kg LW }\end{array}$ & 0.22 & 0.73 & 2.15 & 3.1 & & & & & \\
\hline
\end{tabular}

Notes: 1) breeder/ weaner / grower - finisher national average calculated from (Wiedemann et al., 2016) based on aggregated diets per tonne of ratio for four diets used for the national herd data and land occupation (only wheat and barley data available) multiplied by percentage of production in each

geographic area (49\% in NSW-Vic, $23 \%$ in QId, $11.4 \%$ in WA and 16.6\% in SA), when two values were provided for wheat data for each geographic area, the 
Life cycle assessment of Danish pork exports using different cooling technologies and comparison of upstream supply chain efficiencies between Denmark, China and Australia

lowest was used, 2) (Mogensen et al., 2018), 3) assumed values, 4) FAOSTAT, 5) data taken directly from (Wiedemann et al., 2016), crude protein values include non arable sources, such as blood meal ( $85 \%$ protein), meat and bone meal (50\% protein) and other protein meal such as fishmeal

\section{Table B.2: Detailed information on Danish feed}

\begin{tabular}{|c|c|c|c|c|c|c|}
\hline $\begin{array}{l}\text { Danish feed per } \\
\text { 100kg LW }\end{array}$ & Mass $^{1}$ & $\begin{array}{c}\text { Mass } \\
\%\end{array}$ & $\begin{array}{c}\text { Average } \\
\text { protein } \%^{2}\end{array}$ & $\begin{array}{l}\text { Economic } \\
\text { allocation }\end{array}$ & Feed origin ${ }^{3}$ & $\begin{array}{c}\text { Yield }\left(\mathrm{kg} / \mathrm{m}^{2}\right)^{5} \\
\text { 2016/lowest (year) }\end{array}$ \\
\hline Wheat & 111.2 & $39.5 \%$ & $9.9 \%$ & $84 \%^{3}$ & 100\% Denmark & 0.72 / 0.65 (2011) \\
\hline Barley & 85.5 & $30.4 \%$ & $9.4 \%$ & $99 \%^{3}$ & 100\% Denmark & $0.56 / 0.47(2008)$ \\
\hline Soybean meal & 34.1 & $12.1 \%$ & $45.78 \%$ & $62 \%^{4}$ & $\begin{array}{l}64 \% \text { Argentina, 28\% Brazil, 8\% } \\
\text { USA }\end{array}$ & $\begin{array}{c}2016-0.30,0.29,0.35 \\
\text { Lowest }-0.18 \text { Argentina (2009) }\end{array}$ \\
\hline Sunflower cake & 11 & $3.9 \%$ & $32.75 \%$ & $28 \%^{3}$ & $\begin{array}{l}\text { 14\% Estonia, 5\% Germany, 4\% } \\
\text { Lithuania, 42\% Russia, 35\% } \\
\text { Ukraine, (used Russia yield data } \\
\text { for Estonia \& Lithuania) }\end{array}$ & $\begin{array}{c}2016 \text { - Russia/Estonia/Lithuania - } \\
0.15 \text {, Germany - 0.21, Ukraine - } \\
0.22 \\
\text { Lowest - } 0.10 \text { Russia (2010) }\end{array}$ \\
\hline Rapeseed cake & 11 & $3.9 \%$ & $34.4 \%$ & $28 \%^{4}$ & 100\% Denmark & $0.31 / 0.31(2016)$ \\
\hline Wheat bran & 6.4 & $2.3 \%$ & $14.68 \%$ & $6 \%^{3}$ & 100\% Denmark & $0.72 / 0.65(2011)$ \\
\hline Fish oil & 2.2 & $0.8 \%$ & 0 & $\mathrm{n} / \mathrm{a}$ & Not required & Not applicable \\
\hline Palm oil & 6 & $2.1 \%$ & 0 & $94 \%^{3}$ & 70\% Indonesia, 30\% Malaysia & $\begin{array}{c}2016 \text { - Indon - } 0.39 \text { / Malay - } 0.37 \\
\text { Lowest }-0.35 \text { Indonesia (2008) }\end{array}$ \\
\hline Beet molasses & 5.2 & $1.9 \%$ & $9.62 \%$ & $5 \%^{3}$ & $\begin{array}{l}\text { 10\% Denmark, 34\% Russia, 16\% } \\
\text { Ukraine, } 4 \% \text { Egypt, 36\% India. } \\
\text { nb India used sugar cane yield }\end{array}$ & $\begin{array}{c}\text { 2016 - Denmark - 7.10, Russia - } \\
\text { 4.70, Ukraine - 4.81, Egypt }-4.77 \text {, } \\
\text { India - 7.04 } \\
\text { Lowest - 2.41, Russia (2010) }\end{array}$ \\
\hline Other & 8.7 & $3.1 \%$ & \multicolumn{4}{|c|}{ Minerals + amino acids + special proteins } \\
\hline Total & $2,812.4$ & $100 \%$ & & & & \\
\hline $\begin{array}{l}\text { Whole herd FCR } \\
\mathrm{kg} \text { feed / kg LW }\end{array}$ & 2.8124 & \multicolumn{5}{|c|}{$15.5 \%$ average protein from arable sources, calculated } \\
\hline
\end{tabular}

Notes: 1) (Nguyen et al., 2011), 2) (SEGES Svineproduktion, 2018), 2016 average values, 3) (Mogensen et al. 2018), 4) (Wiedemann, McGahan and Murphy, 2016), 5) FAOSTAT

Table B.3: Detailed information on Chinese pig feed 
Life cycle assessment of Danish pork exports using different cooling technologies and comparison of upstream supply chain efficiencies between Denmark, China and Australia

\begin{tabular}{|c|c|c|c|c|c|c|}
\hline & $\begin{array}{c}\text { Mass } \\
\%^{1}\end{array}$ & $\begin{array}{c}\text { Mass } \\
\%^{2}\end{array}$ & $\begin{array}{l}\text { Average } \\
\text { protein \% }\end{array}$ & $\begin{array}{l}\text { Economic } \\
\text { allocation }\end{array}$ & Feed origin & $\begin{array}{l}\text { Yield }\left(\mathrm{kg} / \mathrm{m}^{2}\right)^{11} \\
2016 / \text { lowest yield (year) }\end{array}$ \\
\hline Corn & $55 \%$ & $63 \%$ & $9.3 \%^{3}$ & $100 \%$ & $100 \%$ China $^{4}$ & $0.60 / 0.53(2009)$ \\
\hline Soymeal & $20 \%$ & $18 \%$ & $48 \%^{5}$ & $62 \%^{5}$ & $\begin{array}{l}\text { 12\% China, 10\% Argentina, } 42.7 \% \\
\text { Brazil, } 34.7 \% \text { USA }\end{array}$ & $\begin{array}{l}2016-\text { China }=0.18, \text { Argentina }= \\
0.30, \text { Brazil }=0.29, \text { USA }=0.27 \\
\text { Lowest }-0.16, \text { China }(2009)\end{array}$ \\
\hline Wheat bran & $5 \%$ & $12 \%$ & $14.68 \%^{7}$ & $6 \%^{8}$ & $100 \%$ China $^{4}$ & 0.54 / 0.47 (2009) \\
\hline Rice bran & $3 \%$ & $0 \%$ & $13.4 \%^{9}$ & $6 \%^{10}$ & $100 \%$ China $^{4}$ & 0.69 / 0.65 (2010) \\
\hline Other & $12 \%$ & $7 \%$ & $\begin{array}{l}9.6 \% \text { for } \\
\text { wheat }^{7}\end{array}$ & $100 \%$ & $\begin{array}{l}\text { Model as 1) } 100 \% \text { sprouted wheat } \\
\text { and 2) non-arable crop source }\end{array}$ & 0.54 / 0.47 (2009) \\
\hline $\begin{array}{l}\text { Whole herd FCR } \\
\text { (kg feed / kg LW) }\end{array}$ & 3.24 & 2.80 & & & & \\
\hline Total protein $\%$ & $\begin{array}{l}17.0 \% \\
15.9 \%\end{array}$ & $\begin{array}{l}16.9 \% \\
16.3 \%\end{array}$ & $\begin{array}{l}\text { 1) Sproute } \\
\text { 2) Non-ara }\end{array}$ & $\begin{array}{l}\text { wheat case } \\
\text { le crop case }\end{array}$ & & \\
\hline
\end{tabular}

Notes: 1) (USDA Foreign Agricultural Service, 2018b) finisher FCR 3.1, 2) (Zhou et al., 2018) finisher FCR 2.68, 3) (Ontaria Ministry of Agriculture Food and Rural Affairs, 2012), 4) (USDA Foreign Agricultural Service, 2018d), 5) (Wiedemann, McGahan and Murphy, 2016), 6) (USDA Foreign Agricultural Service, 2018c), 7) (SEGES Svineproduktion, 2018), 8) (Mogensen et al., 2018), 9) (DTU Food (National Food Institute), 2019), 10) assumed value, 11) FAOSTAT. 
Life cycle assessment of Danish pork exports using different cooling technologies and comparison of upstream supply chain efficiencies between Denmark, China and Australia

Table B.4: Detailed information on origin of feed materials in China, based on trade data (derived from (USDA Foreign Agricultural Service, 2018d, 2018c)

\begin{tabular}{|l|c|c|c|c|}
\hline & $\begin{array}{c}\text { Corn } \\
2016 / 2017 \\
(1000 \text { tons })\end{array}$ & $\begin{array}{c}\text { Wheat } \\
2016 / 2017 \\
(1000 \text { tons })\end{array}$ & $\begin{array}{c}\text { Soy beans } \\
2016 / 2017 \\
(1000 \text { tons })\end{array}$ & $\begin{array}{c}\text { Rice } \\
2016 / 2017 \\
(1000 \text { tons })\end{array}$ \\
\hline Chinese Imports & 4,410 & 2,464 & 93,495 & 4,600 \\
\hline Chinese Exports & 748 & 0 & 114 & 368 \\
\hline Chinese Production & 133,271 & 263,613 & 12,900 & 147,766 \\
\hline Chinese Consumption & 119,000 & 255,000 & 102,800 & 141,761 \\
\hline Ending Stocks & 114,929 & 223,017 & 20,391 & 98,500 \\
\hline \% used in this report & $100 \%$ & $100 \%$ & $12 \%$ & $100 \%$ \\
& Chinese & Chinese & Chinese & Chinese \\
\hline
\end{tabular}

Table B.5: Pork Meat Yield Factor Matrix derived from (Wiedemann and Yan, 2014)

\begin{tabular}{|l|c|c|c|c|}
\hline & LW & HSCW & CW & RC \\
\hline Live Weight (LW) & 1 & 1.32 & 1.37 & 1.79 \\
\hline Hot Standard Carcass Weight (HSCW) & 0.76 & 1 & 1.04 & 1.36 \\
\hline Cold Carcass Weight (CW) & $0.73^{1}$ & 0.96 & 1 & 1.30 \\
\hline Retail Cuts (RC) wholesale & 0.56 & 0.74 & 0.77 & 1 \\
\hline Boneless meat including edible offal & 0.53 & 0.69 & 0.72 & 0.94 \\
\hline
\end{tabular}

Note: 1) value for Denmark in 2016 was 0.76 (Agriculture and Horticulture Development Board, 2018)

Appendix C - Detailed results by pork product, super-chilling technology and market destination

Table C.1: Impacts from processing plant by process area (red indicates highest value, green lowest)

\begin{tabular}{|l|c|c|c|}
\hline \multicolumn{1}{|c|}{ Impact per pig (104 kg) } & $\begin{array}{c}\text { Climate change } \\
\left(\mathrm{kgCO}_{2 \text {-eq }}\right)\end{array}$ & $\begin{array}{c}\text { Acidification } \\
\left(\mathrm{molc} \mathrm{H}^{+}\right)\end{array}$ & $\begin{array}{c}\text { Terrestrial eutrophication } \\
\left(\mathrm{molc}_{\text {eq }}\right)\end{array}$ \\
\hline Farming total & 361.17 & 6.92 & 34.76 \\
\hline Transport from farm & 4.33 & 0.019 & 0.057 \\
\hline Slaughtering total & $\mathbf{1 0 . 5 4}$ & $\mathbf{0 . 0 3}$ & $\mathbf{0 . 0 4 5}$ \\
\hline Washing area & 0.04 & 0.0001 & 0.0001 \\
\hline Black slaughter line & 1.82 & 0.005 & 0.006 \\
\hline Clean slaughter line & 0.70 & 0.003 & 0.004 \\
\hline Organ processing/by-product & 0.42 & 0.002 & 0.002 \\
\hline Chilling & 2.78 & 0.01 & 0.015 \\
\hline Cutting & 0.35 & 0.001 & 0.002 \\
\hline Deboning & 0.70 & 0.002 & 0.004 \\
\hline Cleaning & 0.98 & 0.003 & 0.005 \\
\hline Boiler (process/space heating) & 2.77 & 0.005 & 0.005 \\
\hline Ventilation & 0.14 & 0.0005 & 0.001 \\
\hline Wastewater & 0 & 0 & 0 \\
\hline Others & 0.21 & 0.001 & 0.001 \\
\hline Impact per kg cut & & & \\
\hline
\end{tabular}


Life cycle assessment of Danish pork exports using different cooling technologies and comparison of upstream supply chain efficiencies between Denmark, China and Australia

\begin{tabular}{|l|c|c|c|}
\hline \multicolumn{1}{|c|}{ Impact per pig $(104 \mathrm{~kg})$} & $\begin{array}{c}\text { Climate change } \\
\left(\mathrm{kgCO}_{2 \text {-eq }}\right)\end{array}$ & $\begin{array}{c}\text { Acidification } \\
\left(\text { molc H}_{\text {eq }}\right)\end{array}$ & $\begin{array}{c}\text { Terrestrial eutrophication } \\
\left(\text { molc N }_{\text {eq }}\right)\end{array}$ \\
\hline Cooking (ham only) & 0.06 & 0.001 & 0.001 \\
\hline Packaging & 0.123 & 0.001 & 0.001 \\
\hline General cooling & 0.002 & 0.00001 & 0.00001 \\
\hline
\end{tabular}

Table C.2: Acidification impacts (molc $\mathrm{H}^{+}$eq / $\mathrm{kg}$ cut) after re-allocation of byproducts and avoided production

\begin{tabular}{|c|c|c|c|c|c|c|c|c|}
\hline Market & Technology & 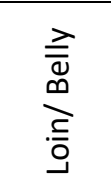 & 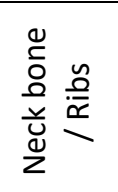 & $\begin{array}{l}\frac{\varepsilon}{\pi} \\
\frac{\pi}{1}\end{array}$ & 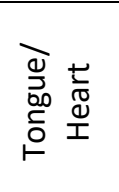 & $\begin{array}{l}\overleftrightarrow{\Xi} \\
\stackrel{\varpi}{\sqcup}\end{array}$ & 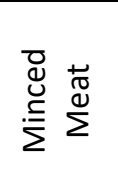 & 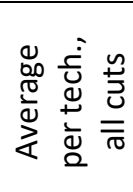 \\
\hline \multirow[t]{5}{*}{ Denmark } & $\begin{array}{l}\text { Impingement } \\
\text { \& spiral }\end{array}$ & 0.064 & 0.064 & 0.065 & 0.064 & 0.064 & 0.064 & 0.065 \\
\hline & Immersion & 0.065 & 0.065 & 0.065 & 0.065 & 0.064 & 0.065 & 0.065 \\
\hline & Chilling room & 0.064 & 0.064 & 0.065 & 0.064 & 0.064 & 0.064 & 0.065 \\
\hline & Contact & 0.064 & $x$ & 0.065 & 0.064 & $x$ & 0.064 & 0.065 \\
\hline & Cryogenic & 0.064 & 0.064 & 0.065 & 0.064 & 0.064 & 0.064 & 0.065 \\
\hline \multirow[t]{5}{*}{$\begin{array}{l}\text { China/ } \\
\text { Australia }\end{array}$} & $\begin{array}{l}\text { Impingement } \\
\& \text { spiral }\end{array}$ & 0.075 & 0.075 & 0.076 & 0.075 & 0.075 & 0.075 & 0.075 \\
\hline & Immersion & 0.075 & 0.075 & 0.076 & 0.075 & 0.075 & 0.075 & 0.075 \\
\hline & Chilling room & 0.075 & 0.075 & 0.076 & 0.075 & 0.075 & 0.075 & 0.075 \\
\hline & Contact & 0.075 & $x$ & 0.076 & 0.075 & $x$ & 0.075 & 0.075 \\
\hline & Cryogenic & 0.075 & 0.075 & 0.076 & 0.075 & 0.075 & 0.075 & 0.075 \\
\hline
\end{tabular}

Table C.3: Terrestrial eutrophication impacts (molc Neq / kg cut) after re-allocation of byproducts and avoided production

\begin{tabular}{|c|c|c|c|c|c|c|c|c|}
\hline Market & Technology & $\begin{array}{l}\frac{\lambda}{\overline{0}} \\
\stackrel{0}{\bar{a}} \\
\frac{\bar{a}}{3}\end{array}$ & 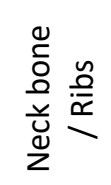 & $\begin{array}{l}\varepsilon \\
\frac{\varepsilon}{T} \\
\frac{\pi}{I}\end{array}$ & 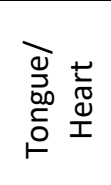 & 芯 & 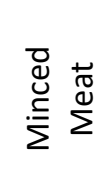 & 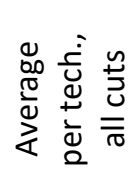 \\
\hline \multirow[t]{5}{*}{ Denmark } & $\begin{array}{l}\text { Impingement } \\
\& \text { spiral }\end{array}$ & 0.336 & 0.336 & 0.337 & 0.336 & 0.336 & 0.336 & 0.336 \\
\hline & Immersion & 0.336 & 0.336 & 0.337 & 0.336 & 0.336 & 0.336 & 0.336 \\
\hline & Chilling room & 0.336 & 0.336 & 0.337 & 0.336 & 0.336 & 0.336 & 0.336 \\
\hline & Contact & 0.336 & $\mathrm{x}$ & 0.337 & 0.336 & $\mathrm{x}$ & 0.336 & 0.336 \\
\hline & Cryogenic & 0.336 & 0.336 & 0.337 & 0.336 & 0.336 & 0.336 & 0.336 \\
\hline \multirow[t]{5}{*}{$\begin{array}{l}\text { China/ } \\
\text { Australia }\end{array}$} & $\begin{array}{l}\text { Impingement } \\
\& \text { spiral }\end{array}$ & 0.346 & 0.346 & 0.347 & 0.346 & 0.346 & 0.346 & 0.346 \\
\hline & Immersion & 0.346 & 0.346 & 0.347 & 0.346 & 0.346 & 0.346 & 0.346 \\
\hline & Chilling room & 0.346 & 0.346 & 0.347 & 0.346 & 0.346 & 0.346 & 0.346 \\
\hline & Contact & 0.346 & $x$ & 0.347 & 0.346 & $x$ & 0.346 & 0.346 \\
\hline & Cryogenic & 0.346 & 0.346 & 0.347 & 0.346 & 0.346 & 0.346 & 0.346 \\
\hline
\end{tabular}

Table C.4: Marine eutrophication impacts (molc Neq / $\mathrm{kg}$ cut) after re-allocation of byproducts and avoided production 
Life cycle assessment of Danish pork exports using different cooling technologies and comparison of upstream supply chain efficiencies between Denmark, China and Australia

\begin{tabular}{|c|c|c|c|c|c|c|c|c|}
\hline Market & Technology & 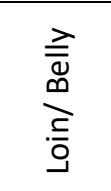 & 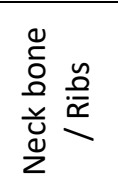 & $\begin{array}{l}\frac{\varepsilon}{\pi} \\
\frac{\pi}{I}\end{array}$ & 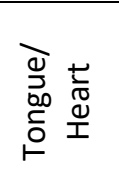 & $\begin{array}{l}\vec{\Phi} \\
\stackrel{\varpi}{\sqcup}\end{array}$ & 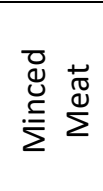 & 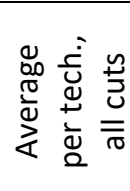 \\
\hline \multirow[t]{5}{*}{ Denmark } & $\begin{array}{l}\text { Impingement } \\
\& \text { spiral }\end{array}$ & 0.054 & 0.054 & 0.054 & 0.053 & 0.053 & 0.054 & 0.054 \\
\hline & Immersion & 0.054 & 0.054 & 0.054 & 0.054 & 0.053 & 0.054 & 0.054 \\
\hline & Chilling room & 0.054 & 0.054 & 0.054 & 0.053 & 0.053 & 0.054 & 0.054 \\
\hline & Contact & 0.054 & $x$ & 0.054 & 0.053 & $\mathrm{x}$ & 0.054 & 0.054 \\
\hline & Cryogenic & 0.054 & 0.054 & 0.054 & 0.053 & 0.053 & 0.054 & 0.054 \\
\hline \multirow[t]{5}{*}{$\begin{array}{l}\text { China/ } \\
\text { Australia }\end{array}$} & $\begin{array}{l}\text { Impingement } \\
\& \text { spiral }\end{array}$ & 0.055 & 0.055 & 0.055 & 0.055 & 0.055 & 0.055 & 0.055 \\
\hline & Immersion & 0.055 & 0.055 & 0.055 & 0.055 & 0.055 & 0.055 & 0.055 \\
\hline & Chilling room & 0.055 & 0.055 & 0.055 & 0.055 & 0.055 & 0.055 & 0.055 \\
\hline & Contact & 0.055 & $x$ & 0.055 & 0.055 & $x$ & 0.055 & 0.055 \\
\hline & Cryogenic & 0.055 & 0.055 & 0.055 & 0.055 & 0.055 & 0.055 & 0.055 \\
\hline
\end{tabular}

Table C.5: Freshwater eutrophication impacts ( $\mathrm{mol}$ Peq / $\mathrm{kg}$ cut) after re-allocation of byproducts and avoided production

\begin{tabular}{|c|c|c|c|c|c|c|c|c|}
\hline Market & Technology & בَّ & 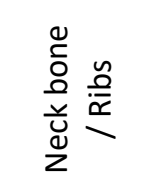 & $\begin{array}{l}E \\
\frac{E}{1}\end{array}$ & 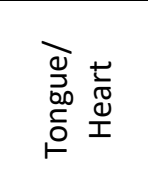 & 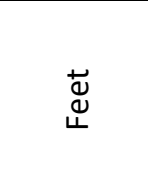 & 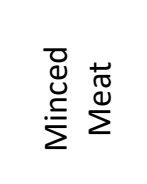 & 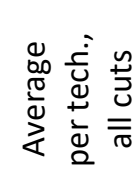 \\
\hline \multirow[t]{5}{*}{ Denmark } & $\begin{array}{l}\text { Impingement } \\
\text { \& spiral }\end{array}$ & -0.00067 & -0.00061 & -0.00059 & -0.00062 & -0.00063 & -0.00062 & -0.00062 \\
\hline & Immersion & -0.00067 & -0.00061 & -0.00059 & -0.00062 & -0.00063 & -0.00061 & -0.00062 \\
\hline & Chilling room & -0.00067 & -0.00061 & -0.00059 & -0.00062 & -0.00063 & -0.00062 & -0.00062 \\
\hline & Contact & -0.00067 & $\mathrm{x}$ & -0.00059 & -0.00062 & $\mathrm{x}$ & -0.00062 & -0.00062 \\
\hline & Cryogenic & -0.00067 & -0.00061 & -0.00059 & -0.00062 & -0.00063 & -0.00062 & -0.00062 \\
\hline \multirow[t]{5}{*}{$\begin{array}{l}\text { China/ } \\
\text { Australia }\end{array}$} & $\begin{array}{l}\text { Impingement } \\
\text { \& spiral }\end{array}$ & -0.00061 & -0.00061 & -0.00059 & -0.00062 & -0.00063 & -0.00062 & -0.00062 \\
\hline & Immersion & -0.00061 & -0.00061 & -0.00059 & -0.00062 & -0.00063 & -0.00062 & -0.00062 \\
\hline & Chilling room & -0.00061 & -0.00061 & -0.00059 & -0.00063 & -0.00063 & -0.00062 & -0.00062 \\
\hline & Contact & -0.00061 & $\mathrm{x}$ & -0.00059 & -0.00063 & $\mathrm{x}$ & -0.00062 & -0.00061 \\
\hline & Cryogenic & -0.00061 & -0.00061 & -0.00061 & -0.00062 & -0.00063 & -0.00062 & -0.00062 \\
\hline
\end{tabular}

Table C.6: Water resource depletion impacts ( $\mathrm{m} 3$ water eq/ $\mathrm{kg}$ cut) after re-allocation of byproducts and avoided production

\begin{tabular}{|c|c|c|c|c|c|c|c|c|}
\hline Market & Technology & $\begin{array}{l}\grave{\overline{0}} \\
\infty \\
\stackrel{\bar{\Xi}}{0}\end{array}$ & 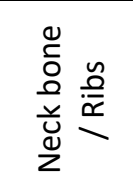 & $\begin{array}{l}\frac{E}{\pi} \\
\text { T⿱一土 }\end{array}$ & 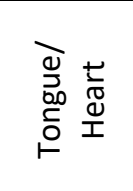 & 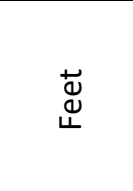 & 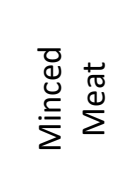 & 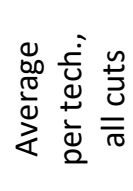 \\
\hline \multirow[t]{4}{*}{ Denmark } & $\begin{array}{l}\text { Impingement } \\
\text { \& spiral }\end{array}$ & -0.0163 & -0.0163 & -0.0158 & -0.0163 & -0.0163 & -0.0163 & -0.0163 \\
\hline & Immersion & -0.0163 & -0.0163 & -0.0158 & -0.0163 & -0.0163 & -0.0163 & -0.0162 \\
\hline & Chilling room & -0.0163 & -0.0163 & -0.0158 & -0.0163 & -0.0163 & -0.0163 & -0.0163 \\
\hline & Contact & -0.0163 & $\mathrm{x}$ & -0.0158 & -0.0163 & $\mathrm{x}$ & -0.0163 & -0.0162 \\
\hline
\end{tabular}


Life cycle assessment of Danish pork exports using different cooling technologies and comparison of upstream supply chain efficiencies between Denmark, China and Australia

\begin{tabular}{|c|c|c|c|c|c|c|c|c|}
\hline Market & Technology & $\begin{array}{l}\overrightarrow{\overline{0}} \\
\infty \\
. \overline{0}\end{array}$ & 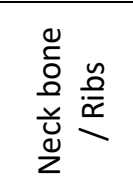 & $\begin{array}{l}\frac{E}{\pi} \\
\text { IT }\end{array}$ & 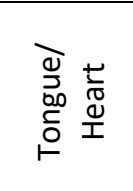 & $\begin{array}{l}\vec{\Phi} \\
\stackrel{\Xi}{L}\end{array}$ & 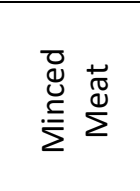 & 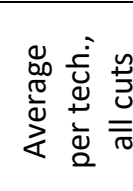 \\
\hline & Cryogenic & -0.0163 & -0.0163 & -0.0158 & -0.0163 & -0.0163 & -0.0163 & -0.0163 \\
\hline \multirow[t]{5}{*}{$\begin{array}{l}\text { China / } \\
\text { Australia }\end{array}$} & $\begin{array}{l}\text { Impingement } \\
\& \text { spiral }\end{array}$ & -0.0161 & -0.0161 & -0.0157 & -0.0161 & -0.0162 & -0.0161 & -0.0161 \\
\hline & Immersion & -0.0161 & -0.0161 & -0.0156 & -0.0161 & -0.0161 & -0.0161 & -0.0161 \\
\hline & Chilling room & -0.0161 & -0.0161 & -0.0157 & -0.0161 & -0.0162 & -0.0161 & -0.0161 \\
\hline & Contact & -0.0161 & $\mathrm{x}$ & -0.0157 & -0.0161 & $\mathrm{x}$ & -0.0161 & -0.0160 \\
\hline & Cryogenic & -0.0161 & -0.0161 & -0.0161 & -0.0161 & -0.0161 & -0.0161 & -0.0161 \\
\hline
\end{tabular}

Table C.7: Land use impacts (kg C deficit/kg cut) after re-allocation of byproducts and avoided production

\begin{tabular}{|c|c|c|c|c|c|c|c|c|}
\hline Market & Technology & 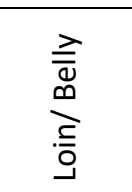 & 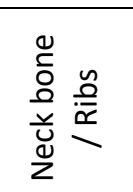 & $\begin{array}{l}\frac{\varepsilon}{10} \\
\frac{\pi}{I}\end{array}$ & 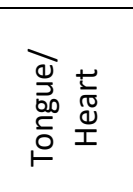 & 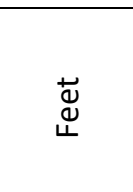 & 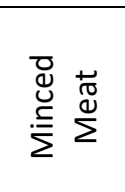 & 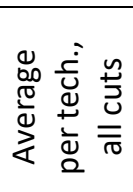 \\
\hline \multirow[t]{5}{*}{ Denmark } & $\begin{array}{l}\text { Impingement } \\
\text { \& spiral }\end{array}$ & 488.29 & 488.28 & 488.36 & 488.25 & 488.22 & 488.27 & 488.28 \\
\hline & Immersion & 488.29 & 488.29 & 488.37 & 488.26 & 488.23 & 488.28 & 488.29 \\
\hline & Chilling room & 488.28 & 488.28 & 488.36 & 488.25 & 488.22 & 488.27 & 488.28 \\
\hline & Contact & 488.28 & $x$ & 488.36 & 488.25 & $x$ & 488.27 & 488.28 \\
\hline & Cryogenic & 488.29 & 488.29 & 488.36 & 488.25 & 488.22 & 488.27 & 488.28 \\
\hline \multirow[t]{5}{*}{$\begin{array}{l}\text { China/ } \\
\text { Australia }\end{array}$} & $\begin{array}{l}\text { Impingement } \\
\text { \& spiral }\end{array}$ & 488.89 & 488.89 & 488.97 & 488.86 & 488.83 & 488.88 & 488.89 \\
\hline & Immersion & 488.90 & 488.90 & 488.98 & 488.87 & 488.84 & 488.89 & 488.90 \\
\hline & Chilling room & 488.89 & 488.89 & 488.97 & 488.86 & 488.83 & 488.88 & 488.89 \\
\hline & Contact & 488.89 & $x$ & 488.97 & 488.86 & $x$ & 488.88 & 488.89 \\
\hline & Cryogenic & 488.90 & 488.89 & 488.89 & 488.86 & 488.83 & 488.88 & 488.88 \\
\hline
\end{tabular}

Table C.8: Impacts for farming and processing per kg of ham, before and after re-allocation of byproducts and avoided production (i.e. without super-chilling and transport to final market).

\begin{tabular}{|l|c|c|c|}
\hline Indicator per kg & Before & After & $\%$ change \\
\hline Climate change $\left(\mathrm{kg} \mathrm{CO}_{2-\mathrm{e}}\right.$ ) & 4.036 & 3.426 & $15 \%$ better \\
\hline Acidification $\left(\mathrm{molc} \mathrm{H}^{+}\right.$eq) & 0.073 & 0.065 & $12 \%$ better \\
\hline Terrestrial eutrophication (molc Neq $/ \mathrm{kg})$ & 0.358 & 0.336 & $6 \%$ better \\
\hline Marine eutrophication (kg N eq) & 0.052 & 0.054 & $3 \%$ worse \\
\hline Freshwater eutrophication (kg P eq) & 0.001 & -0.001 & $173 \%$ better \\
\hline Water resource depletion (m ${ }^{3}$ water) & 0.009 & -0.016 & $268 \%$ better \\
\hline Land use (kg C deficit) - before & 417 & 488 & $17 \%$ worse \\
\hline
\end{tabular}

